INTERNATIONAL MONETARY FUND

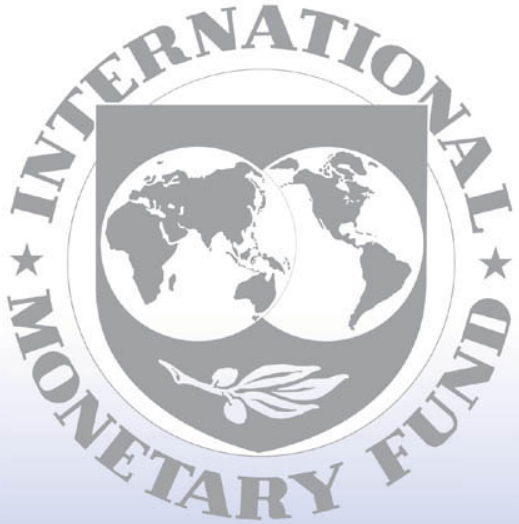

Staff

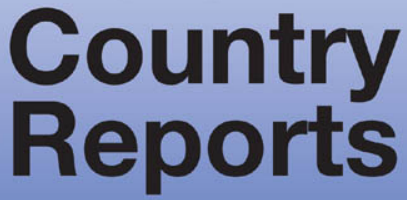




\section{People's Republic of China-Hong Kong Special Administrative Region: 2007 Article IV Consultation-Staff Report; and Public Information Notice on the Executive Board Discussion}

Under Article IV of the IMF's Articles of Agreement, the IMF holds bilateral discussions with members, usually every year. In the context of the 2007 Article IV consultation with People's Republic of China-Hong Kong Special Administrative Region, the following documents have been released and are included in this package:

- $\quad$ The staff report for the 2007 Article IV consultation discussions, prepared by a staff team of the IMF, following discussions that ended on November 7, 2007, with the officials of People's Republic of China-Hong Kong Special Administrative Region on economic developments and policies. Based on information available at the time of these discussions, the staff report was completed on December 21, 2007. The views expressed in the staff report are those of the staff team and do not necessarily reflect the views of the Executive Board of the IMF.

- $\quad$ A Public Information Notice (PIN) summarizing the views of the Executive Board as expressed during its January 18, 2008 discussion of the staff report that concluded the Article IV consultation discussions.

The document listed below has been or will be separately released.

\section{Selected Issues Paper}

The policy of publication of staff reports and other documents allows for the deletion of market-sensitive information.

To assist the IMF in evaluating the publication policy, reader comments are invited and may be sent by e-mail to publicationpolicy@imf.org.

Copies of this report are available to the public from

International Monetary Fund • Publication Services

$70019^{\text {th }}$ Street, N.W. • Washington, D.C. 20431

Telephone: (202) 623-7430 • Telefax: (202) 623-7201

E-mail: publications@imf.org • Internet: http://www.imf.org

Price: $\$ 18.00$ a copy

\section{International Monetary Fund Washington, D.C.}


This page intentionally left blank

CInternational Monetary Fund. Not for Redistribution 
INTERNATIONAL MONETARY FUND

\section{PEOPLE'S REPUBLIC OF CHINA-HONG KONG SPECIAL ADMINISTRATIVE REGION}

\section{Staff Report for the 2007 Article IV Consultation Discussions}

Prepared by the Staff Representatives for the 2007 Consultation Discussions with Hong Kong Special Administrative Region

Approved by Steven Dunaway and Anthony R. Boote

December 21, 2007

Discussions: Hong Kong SAR, October 29-November 7, 2007. The team met with Financial Secretary John Tsang, Hong Kong Monetary Authority Chief Executive Joseph Yam, Financial Services and the Treasury Secretary K. C. Chan, and other senior government officials and private sector representatives.

Team: Messrs. Aziz (Head), Porter, and Vitek (all APD), and Mses. Cui (APD) and Loukoianova (MCM); Mr. Unteroberdoerster (Resident Representative) assisted the mission. Mr. Dunaway joined the mission for the concluding discussions. Mr. Ge, Executive Director, and Ms. Lo (OED) joined the mission.

Economic setting: Economic growth remains strong as Hong Kong SAR's financial integration with the Mainland deepens. The merchandise trade deficit has widened and the current account surplus has declined. Inflation is modest, and unemployment is at its lowest in almost a decade.

Focus: Hong Kong SAR's medium-term competitiveness as a financial center.

Past Fund advice: The Fund has generally supported the authorities' policies and reforms, including the authorities' commitment to the Linked Exchange Rate System (LERS).

Exchange arrangement: Currency board - the LERS — with a trading band of Hong Kong dollar 7.75-7.85 per U.S. dollar. Obligations under Article VIII have been accepted for Hong Kong SAR, and the exchange system is free of restrictions for current international transactions. 
Executive Summary $\underline{3}$

I. Recent Developments and Outlook $\underline{4}$

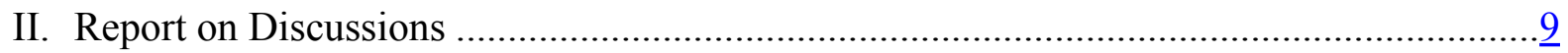

A. Exchange Rate, Money Markets, and the LERS .................................................11

B. Financial Market Development and Competitiveness .............................................

C. Near- and Medium-Term Fiscal Policy ................................................................

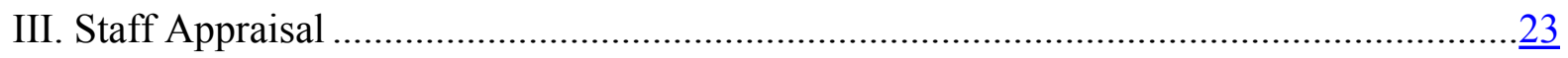

Figures

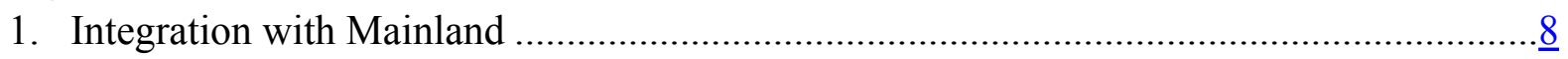

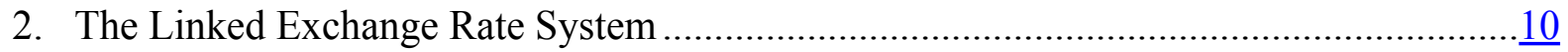

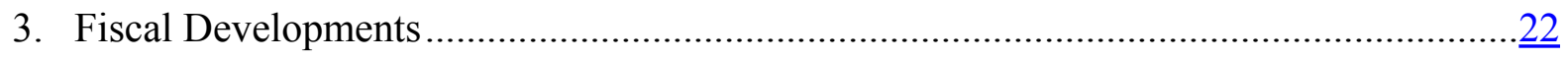

Tables

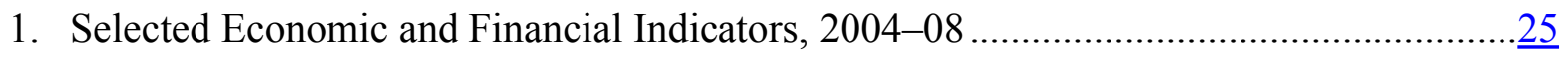

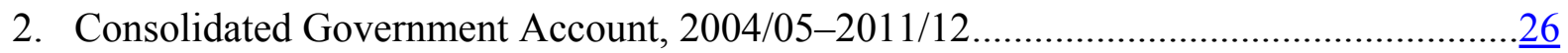

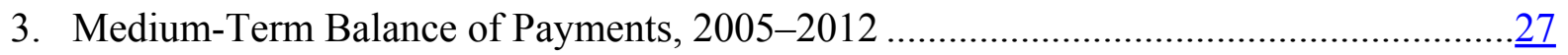

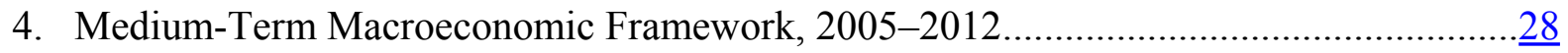

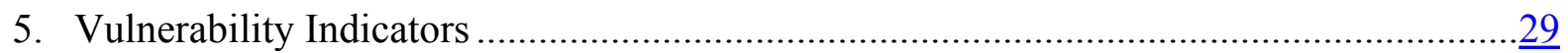




\section{EXECUTIVE SUMMARY ${ }^{1}$}

\section{Economic Setting}

Hong Kong SAR grew strongly-around 71/2 percent annually-during 2004 to 2006. This performance reflects Hong Kong SAR's successful transformation from a manufacturing presence to a services hub over past decades. Recently growth has been driven by domestic demand, with private construction beginning to recover after a decade-long decline. Unemployment is at its lowest in almost a decade, while inflation is moderate. Nonetheless, weakening external demand is likely to see growth moderate to less than 5 percent in 2008, with strong import demand widening the merchandise trade deficit further. Over the medium term, much will depend on how integration with the Mainland is managed.

\section{Policy Discussions}

The consultation discussions focused on the SAR's medium-term competitiveness as a financial center.

- Exchange rate policy: Staff supports the authorities' commitment to the LERS. The LERS has been fortified by the 2005 refinements and has been able to cope well with periodic pressures including during this October. Nonetheless, frictions in the money market - that may cause episodic anomalies between the exchange rate and interest rates — should be ironed out, while domestic market flexibility needs to be safeguarded. Quantitative and qualitative evidence suggests the Hong Kong dollar is valued in line with fundamentals.

- $\quad$ Financial center development: Hong Kong SAR's future as a financial center is linked to its expanding role in Mainland intermediation. Proposals for increased equity market integration are under consideration, renminbi bond issuance has commenced locally, while local banks are expanding their Mainland presence. That said, the range of investment products in Hong Kong SAR should be expanded, and continued financial stability preserved.

- $\quad$ Fiscal policy: While the current fiscal stance is appropriate, some fiscal reforms remain pending. Particular challenges are prospective aging-related healthcare spending, and the highly volatile revenue. Healthcare financing reform proposals are expected in early 2008. The new arrangements to smooth fiscal investment income are welcome, but there remains a need to broaden the tax base.

\footnotetext{
${ }^{1}$ This report was prepared using data available prior to December 3, 2007.
} 


\section{RECENT DEVELOPMENTS AND OUTLOOK}

\section{A decade of structural changes has transformed Hong Kong SAR into a}

service-based economy. This transformation was not easy as the economy was hit by three large external shocks in quick succession - the Asian crisis (1998), the bursting of the IT bubble (2001), and the SARS outbreak (2003). However, Hong Kong SAR's flexible labor and product markets, supported by a surging Mainland economy, strong institutions, and prudent fiscal policy that played a crucial role as the linked-exchange rate system (LERS) precluded active monetary policy, helped to transform the economy into a concentration of financial and business services. Today, Hong Kong SAR's economic structure resembles more that of a global city than that of an advanced country. Even the conventional comparison with Singapore appears stretched given the continuing importance of manufacturing there. Only when the adjacent manufacturing-center of the Pearl River Delta, where many Hong Kong industries have relocated, is included does the combined economic structure look like a typical advanced economy.
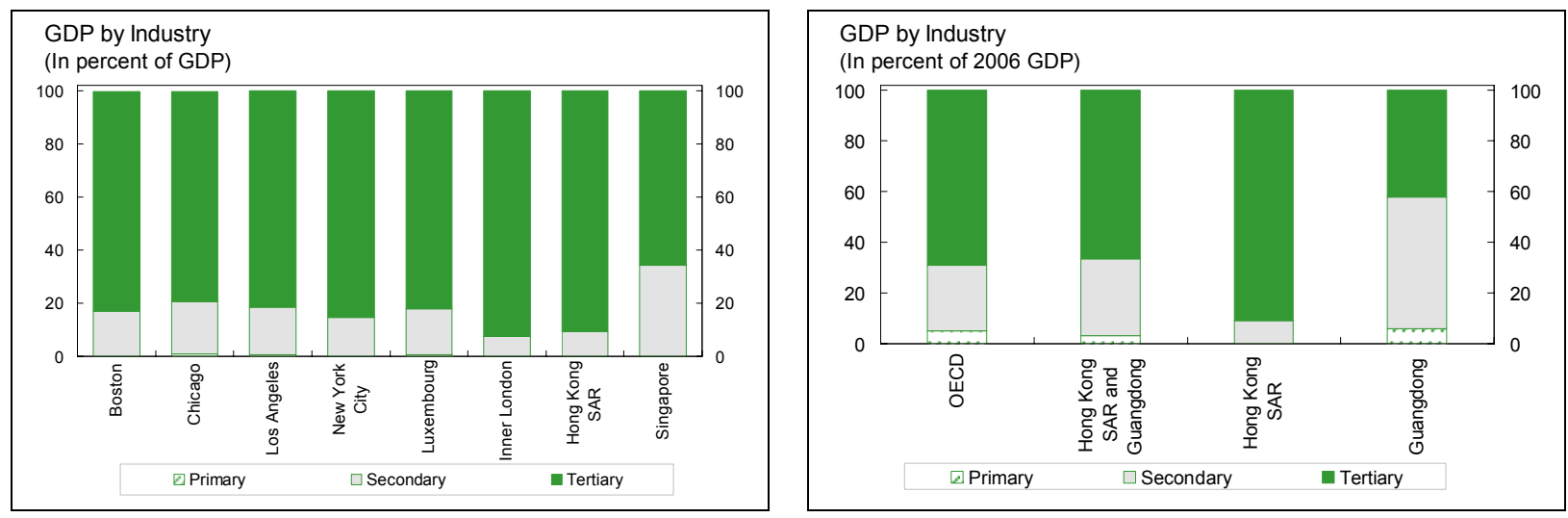

\section{Aided by the flexibility of Hong Kong SAR's markets and the success of this} transformation, economic growth averaged around 71/2 percent during 2004 to 2006. Following growth of 6.8 percent in 2006, the economy grew by 6.1 percent in the first three-quarters of 2007. Domestic demand has been the main driver of growth. With unemployment falling to a nearly ten-year low (3.9 percent in October), and incomes and asset prices robust, consumption grew strongly. Importantly private sector construction is also starting to recover after an almost decade long decline. Inflation has been low, partly reflecting temporary budgetary measures that have held down housing costs. 

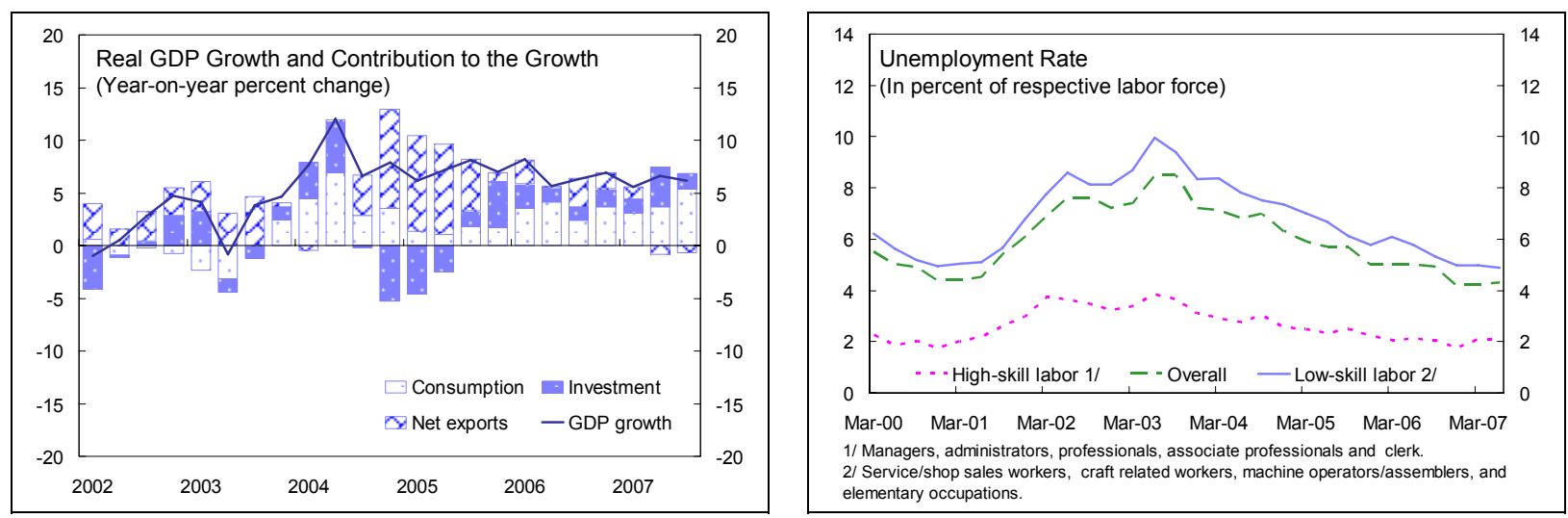

3. Strong import demand has widened the merchandise trade deficit. However, rising investment income has limited the decline in the current account surplus, which has fallen to 12 percent of GDP in the first half of 2007 from around 15 percent of GDP in the second half of 2006. Although capital inflows remain strong, outflows have picked up as Mainland banks transferred part of the funds they raised in IPOs last year.
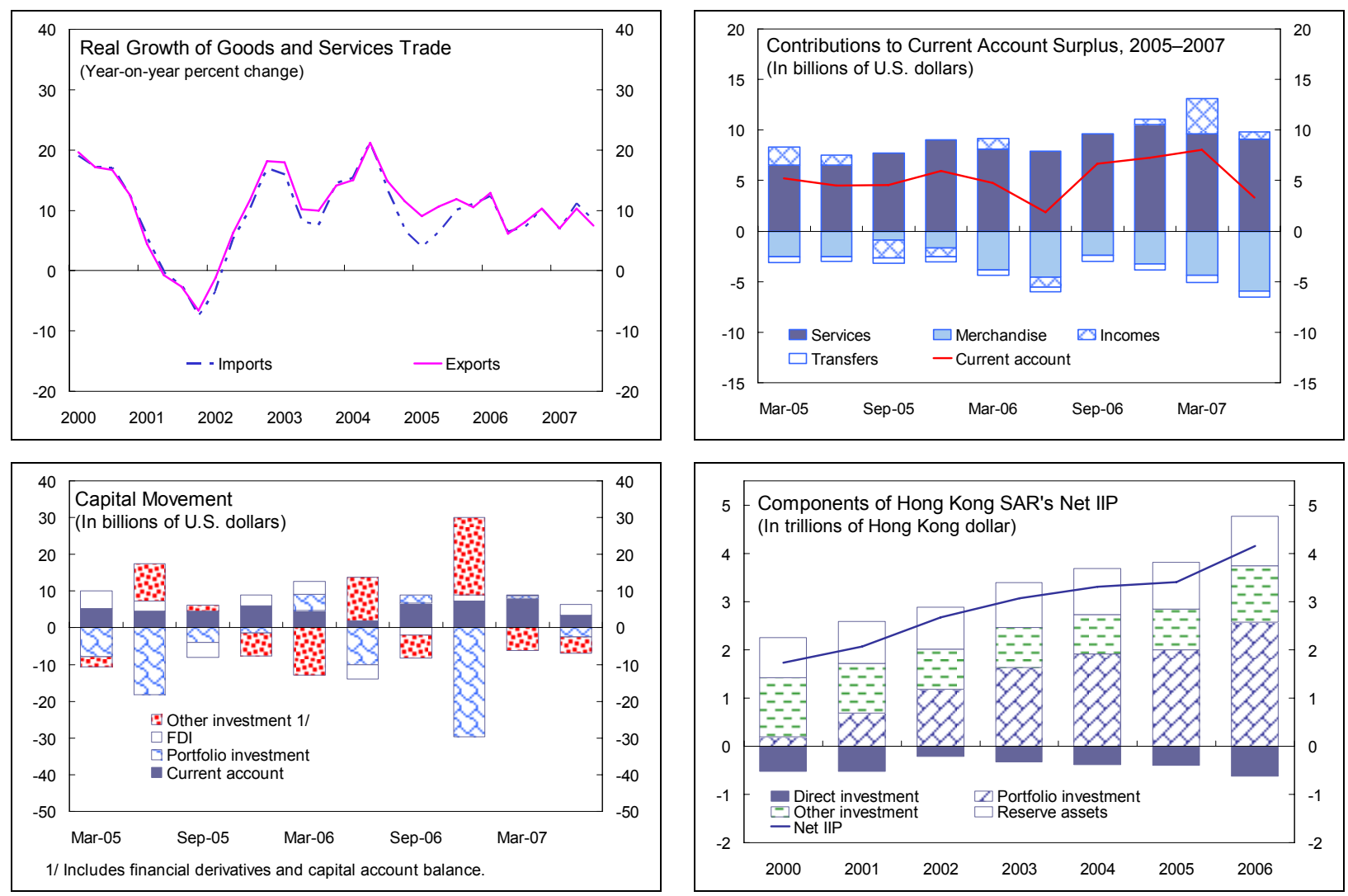

4. Despite some volatility in recent months, banks, corporates and households are

healthy. Expectations of the Mainland allowing its residents to invest in Hong Kong markets (the "through train" individual investment scheme), led to a rapid rise in stock prices and equity-related derivative issuance. However, prices reversed sharply when the Mainland announced in early November that progress on the "through train" individual investment 
scheme would take more time than envisaged as modalities still needed to be worked out. ${ }^{2}$ Notwithstanding this volatility, banks and other financial institutions are well capitalized, and profitability and asset quality have improved. Similarly, corporate and household balance sheets are also strong with declining longer-term debt driving significant deleveraging. Available data suggests that financial sector exposures (across banks and asset management companies) to subprime mortgages and other structured products are low; market analyses of equity market valuation and balance sheet information also indicate that default probabilities are small.
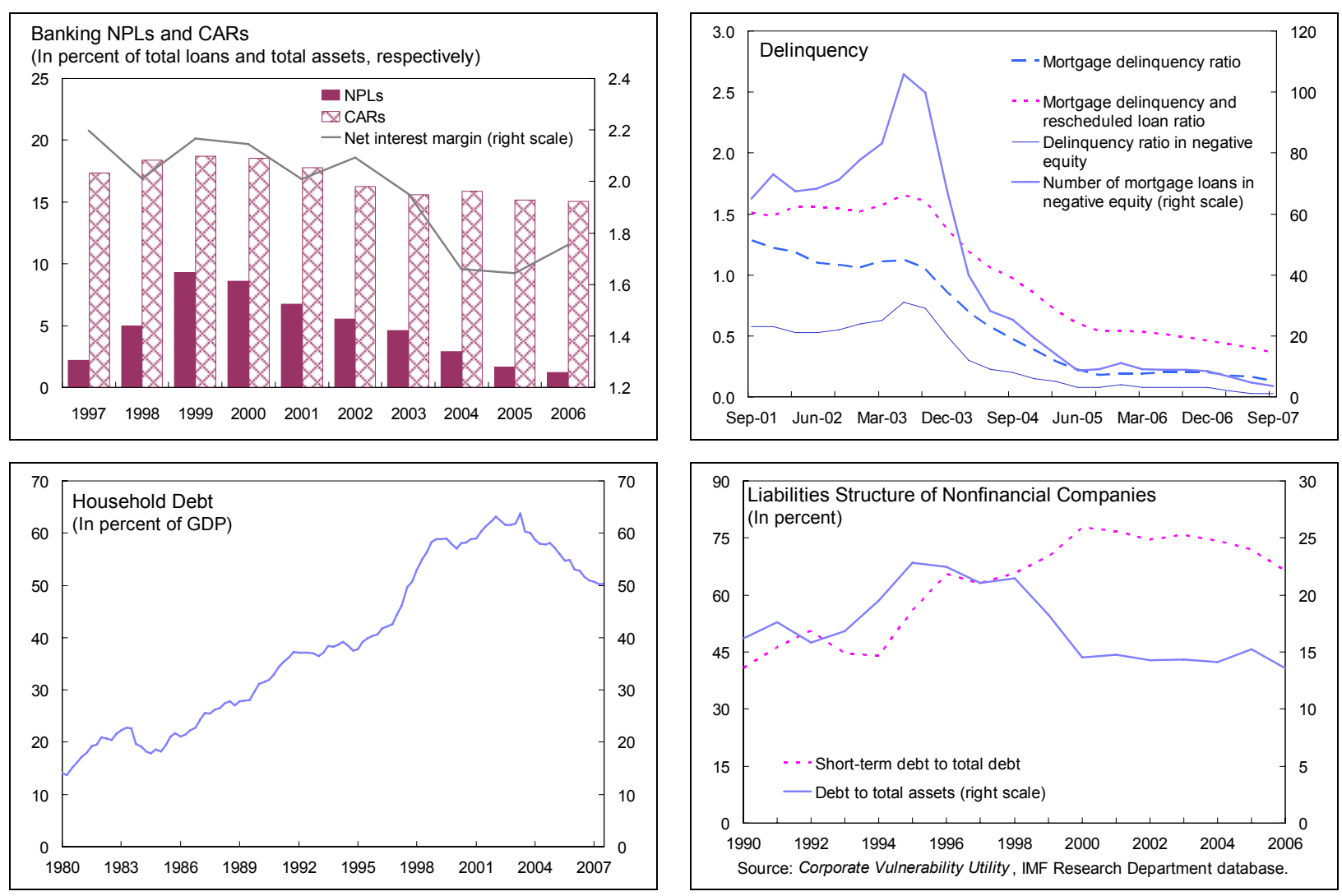

\section{While the Hong Kong dollar (HKS) has generally fluctuated within its trading} band, a confluence of events pushed the currency to appreciate to the strong side of the band during late-October. Cuts in the Fed funds rate prompted an unwinding of long U.S. dollar (US\$) positions, while a bunching of oversubscribed IPOs and strong demand for Mainland-related equities tightened domestic liquidity conditions, raising HK\$ interest rates above comparable US\$ rates. ${ }^{3}$ Together these pushed the HK\$ to the strong side of the

\footnotetext{
${ }^{2}$ The scheme was proposed in August and if implemented as proposed would allow Mainland investors easy access to Hong Kong markets.

${ }^{3}$ The average amount of funds committed for retail IPO subscriptions rose from HK\$410 billion per month (for average monthly IPO fundraising of HK\$17 billion) between January and August of 2007, to HK\$905 billion (for HK\$39 billion IPO funds raised) between September and early November. In addition to the bunching of
} 
trading band (HK\$7.75/US\$) in October. This prompted the Hong Kong Monetary Authority (HKMA) to intervene in late October, first actively (buying \$100 million) and then passively (\$1.1 billion). ${ }^{4}$ These interventions were unsterilized and in their aftermath interest rates have eased below U.S. interest rates and the HK\$ has again traded well inside the band.

\section{Looking ahead, growth is expected to slow to below 5 percent in 2008 largely due}

to a moderation in global demand. Rising incomes should keep domestic demand strong while widening the trade deficit that should reduce the current account surplus. The labor market would likely tighten further which, together with rising rents (as the temporary budgetary measures that kept housing costs down) and further renminbi appreciation should increase inflation. ${ }^{5}$ The biggest risk to this outlook is a more-than-expected deterioration in external demand especially in the United States and Europe, and potentially further financial turbulence, both internationally (if the fall out from the subprime turmoil deepens) as well as domestically (if the correction in Mainland-related equity prices is sharper and prolonged). ${ }^{6}$ Inflation risks are on the upside.

\section{Over the medium term, much will depend on how well the financial integration} with the Mainland is deepened. Trade integration with the Mainland was completed long ago, and services and financial integration is now poised to deepen. The benefits from

\footnotetext{
IPOs, the need to finance the increase in transactions-RTGS turnover increased by almost 100 percent while stock market turnover increased by almost 350 percent over the year to October-presented challenges to banks' liquidity management.
}

\footnotetext{
${ }^{4}$ The passive intervention took place when the exchange of US\$ for HK\$ was initiated by commercial banks with the HKMA at the strong end of the band as per the convertibility undertaking under the LERS.
}

\footnotetext{
${ }^{5}$ These budget measures that limited housing costs were a waiver of property rates in the June and September quarters of 2007 (up to HK $\$ 5,000$ per quarter). These had an estimated fiscal cost of $0.3-0.4$ percent of GDP, and were initially expected to end in October, but were extended to also include the first quarter of 2008 in the Chief Executive's October Policy Address. Moreover, while a stronger renminbi may increase inflationary pressures, productivity growth and diversification of imports sources can partly mitigate the inflationary pressure - the HKMA has estimated that a 10 percent appreciation in the renminbi would increase the SAR's inflation rate by roughly 0.4 percentage points, as only about 9-17 percent of imports retained in Hong Kong SAR come from the Mainland.

${ }^{6}$ Renminbi appreciation will also affect Hong Kong reexports via its impact on China's exports. But with potentially higher imports to China and Hong Kong SAR's improved domestic competitiveness, especially in low-value added services, the net impact of a moderately large renminbi appreciation on the Hong Kong economy should be small. Greater renminbi flexibility will increase demand for renminbi hedging products; while difficult to quantify, this will benefit Hong Kong financial markets.
} 
Figure 1. Hong Kong SAR: Integration with the Mainland

China occupies the lion's share of Hong Kong's re-exports, with the...

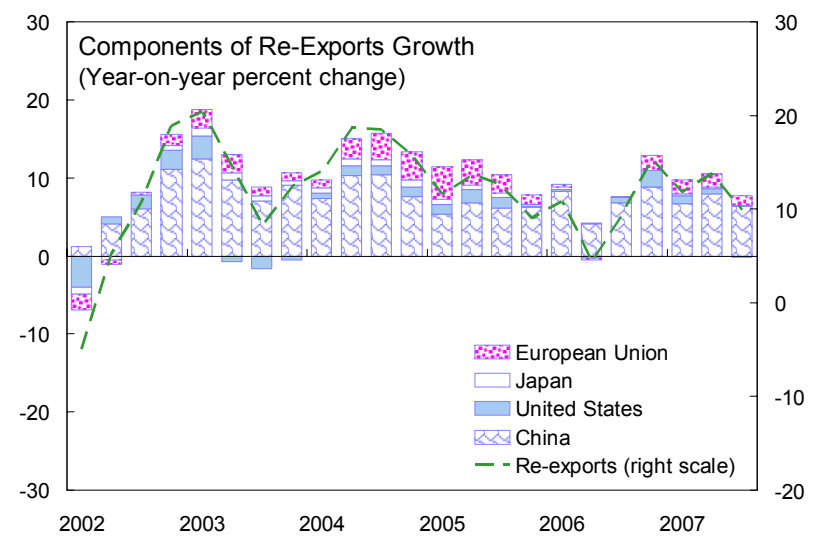

IPO fund raising has moderated after two record high years, but post IPO fund raising is growing.

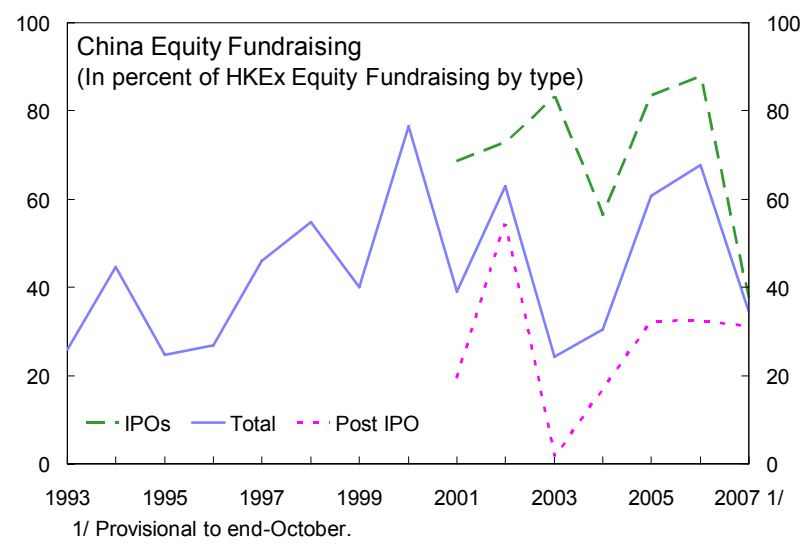

$R M B$ deposits remain low, but have moved out of time deposits ahead of RMB bond issuance.

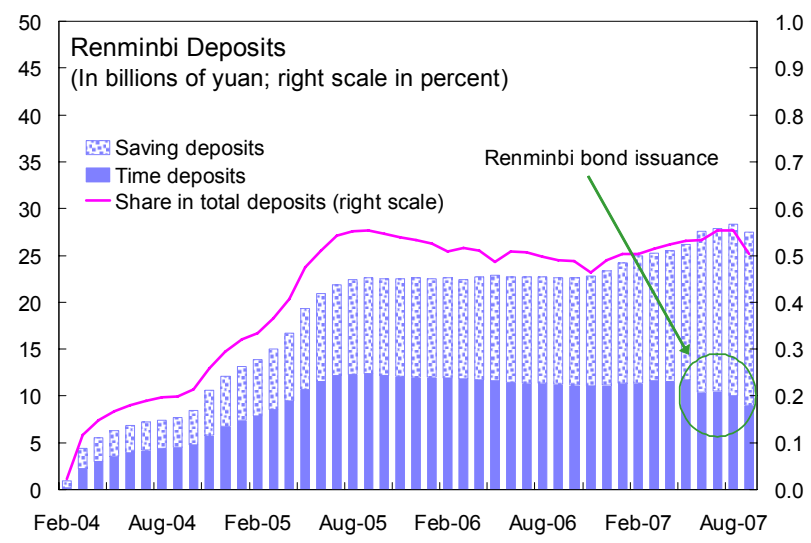

...market capitalization of China firms continuing to rise.

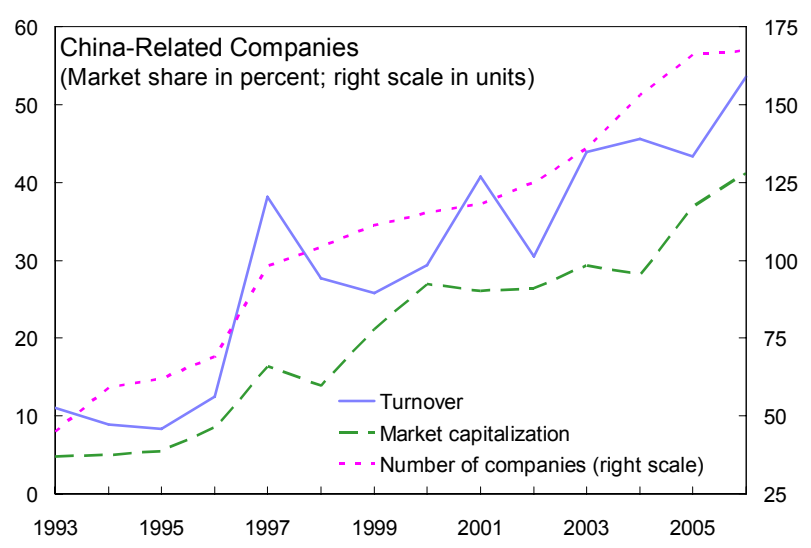

Income from Mainland investment has risen.

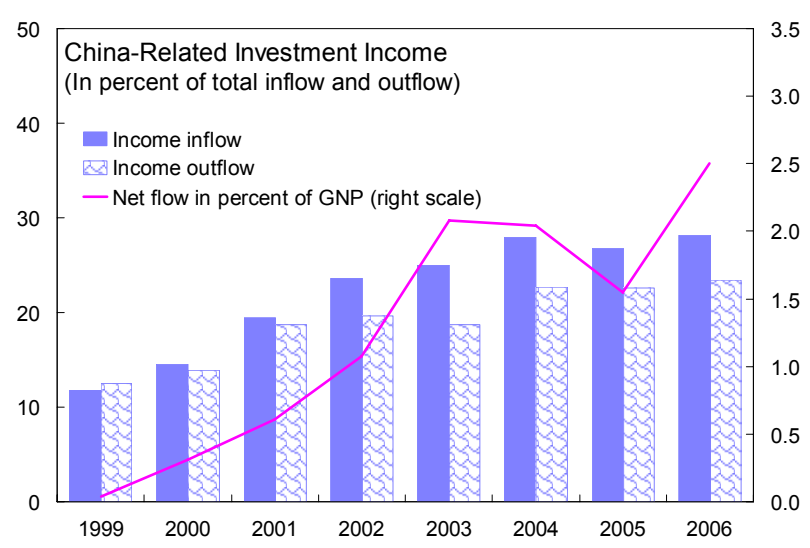

Mainland-related lending by Hong Kong banks has risen to around 20 percent of all lending.

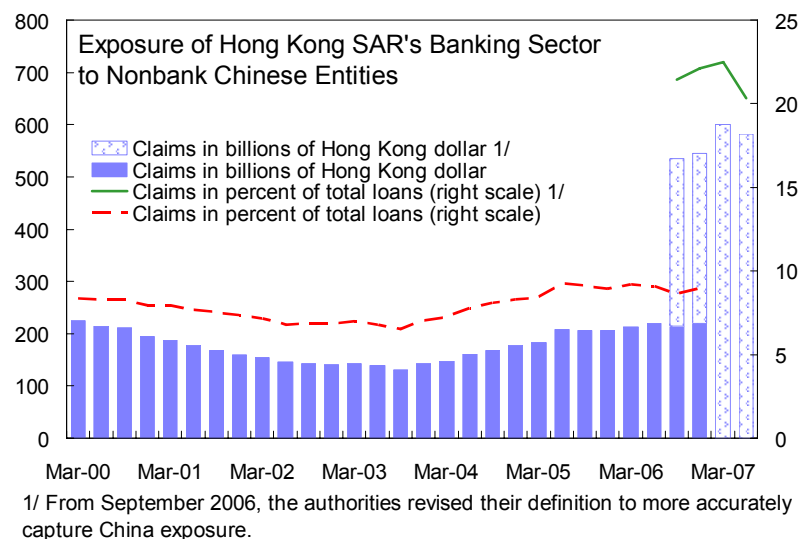

Sources: CEIC Data Co., Ltd.; Hong Kong Monetary Authority; and Fund staff estimates. 
this integration are clear, but it also brings with it associated risks, although these should be limited as long as China sustains its strong growth. ${ }^{7}$ If the integration is managed well and competitive pressures from other regional financial centers withstood, then growth could average around 5 percent. Unemployment will remain low and inflation should pick up modestly.

\begin{tabular}{|c|c|c|c|c|c|c|c|}
\hline \multicolumn{8}{|c|}{$\begin{array}{c}\text { Hong Kong SAR: Medium-Term Projections, } 2006-12 \\
\text { (Percentage change from the previous period, unless otherwise indicated) }\end{array}$} \\
\hline & 2006 & 2007 & 2008 & 2009 & 2010 & 2011 & 2012 \\
\hline Real GDP & 6.8 & 6.0 & 4.6 & 4.9 & 5.0 & 5.0 & 5.0 \\
\hline Total domestic demand & 5.8 & 7.0 & 5.8 & 5.1 & 5.0 & 5.0 & 4.8 \\
\hline Net exports (contribution) & 1.7 & 0.0 & -0.5 & 0.4 & 0.5 & 0.6 & 0.8 \\
\hline Unemployment rate (percent) & 4.8 & 4.1 & 4.0 & 3.8 & 3.6 & 3.5 & 3.3 \\
\hline CPI inflation & 2.0 & 2.2 & 3.7 & 4.1 & 4.6 & 5.0 & 5.0 \\
\hline \multicolumn{8}{|l|}{ Savings-investment balances $1 /$} \\
\hline Private & 8.4 & 8.2 & 6.0 & 5.0 & 4.3 & 3.4 & 2.8 \\
\hline Public & 2.3 & 2.6 & 2.8 & 3.2 & 3.5 & 3.8 & 4.3 \\
\hline Current account balance $1 /$ & 10.6 & 10.8 & 8.9 & 8.3 & 7.8 & 7.2 & 7.1 \\
\hline Goods and services balance 1/ & 11.4 & 10.3 & 8.3 & 7.4 & 6.6 & 5.9 & 5.8 \\
\hline Capital and financial account balance $1 /$ & -13.7 & -10.7 & -8.6 & -7.9 & -7.2 & -6.5 & -6.2 \\
\hline Foreign exchange reserves $1 /$ & 70.2 & 75.4 & 72.7 & 69.6 & 66.2 & 62.8 & 59.2 \\
\hline
\end{tabular}

\section{REPORT ON DISCUSSIONS}

\section{This year's Article IV consultation discussions focused on key aspects of Hong}

Kong SAR's competitiveness as a financial center, as it seeks to expand the role it can play in helping to improve financial intermediation in China. Key aspects of this relate to price competitiveness; the continued smooth operation of the LERS; recent initiatives to use Hong Kong SAR's financial platform for fundraising and as a gateway for Mainland capital account liberalization; as well as policies to limit the risk of revenue volatility and agingrelated fiscal pressures from endangering the economy's low-tax environment.

\footnotetext{
${ }^{7}$ A recent HKMA study (He, Dong, and others, 2006, "The Macroeconomic Impact on Hong Kong of Hypothetical Mainland Shocks,” HKMA Research Memorandum 15/2005 (Hong Kong SAR: HKMA)) simulated a number of scenarios to understand the extent and nature of Mainland-related shocks, such as a rise in protectionist sentiment against the Mainland and financial sector instability in China. While the magnitude of these shocks was large - often representing more than two-standard deviations of historical volatility - the simulated effect on Hong Kong SAR was moderate and none of the shocks resulted in a slowdown similar to that during the Asian crisis, when growth fell dramatically in the first year. For example, a 20 percentage point decline in China's export growth in one year slows Hong Kong SAR's GDP growth by 6 percentage points over two years.
} 


\section{Figure 2. Hong Kong SAR: The Linked Exchange Rate System}

Since the May 2005 refinements, the Hong Kong dollar has moved within its trading band...

The Linked Exchange Rate System

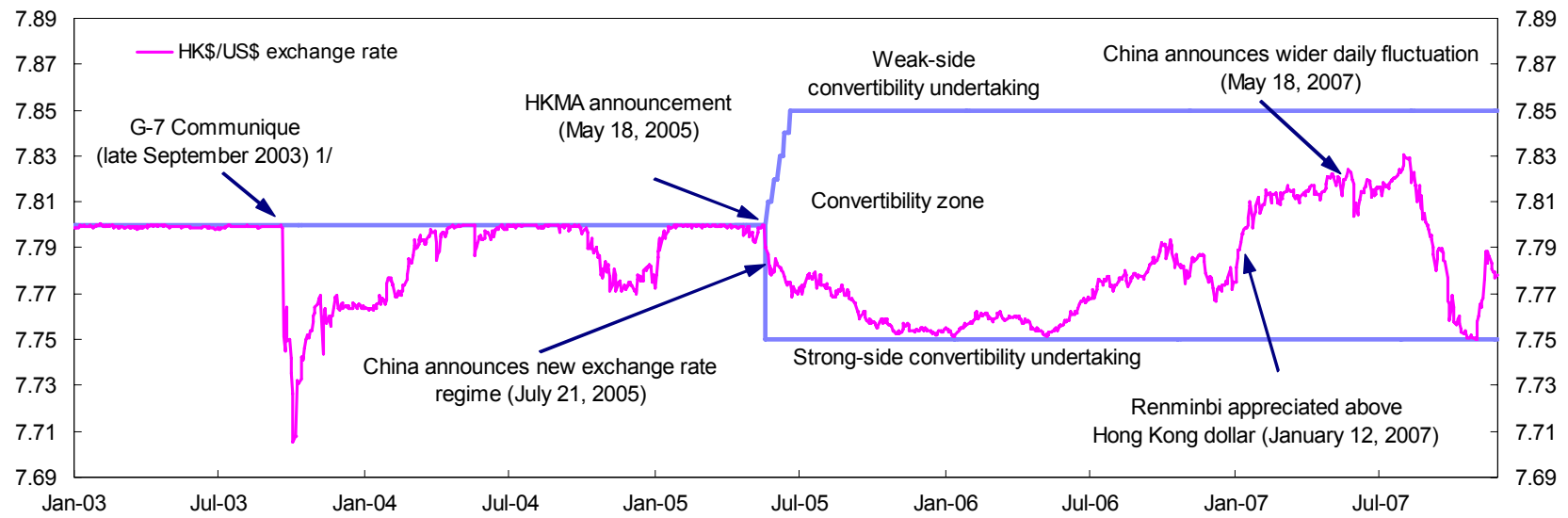

1/ The G-7 Communique statement that "more flexibility in exchange rates is desirable for major countries or economic areas to promote smooth and widespread adjustments in the international financial system" prompted speculation around a possible revaluation of the renminbi and the Hong Kong dollar.

...even though expectations of renminbi appreciation have grown.

Renminbi Non-Deliverable Forward Rates

(Renminbi/U.S. dollar)

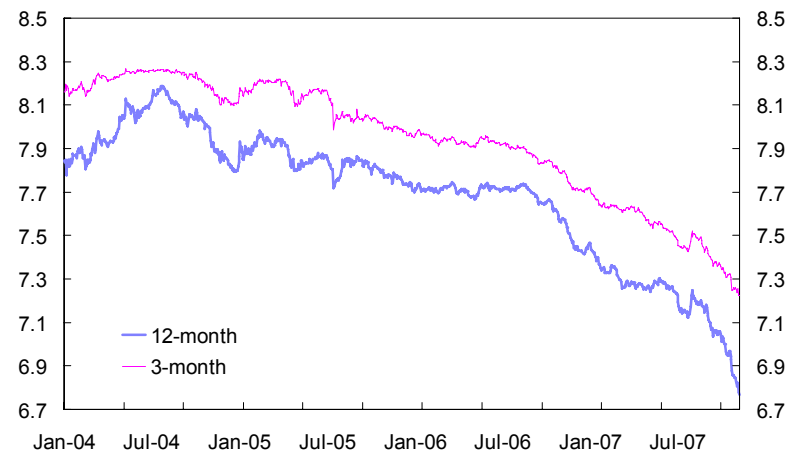

Volatile liquidity demand drove a rapid rise in HIBOR rates prior to the October intervention.

Recent Deviations Between HIBOR and LIBOR

\section{(In percent)}

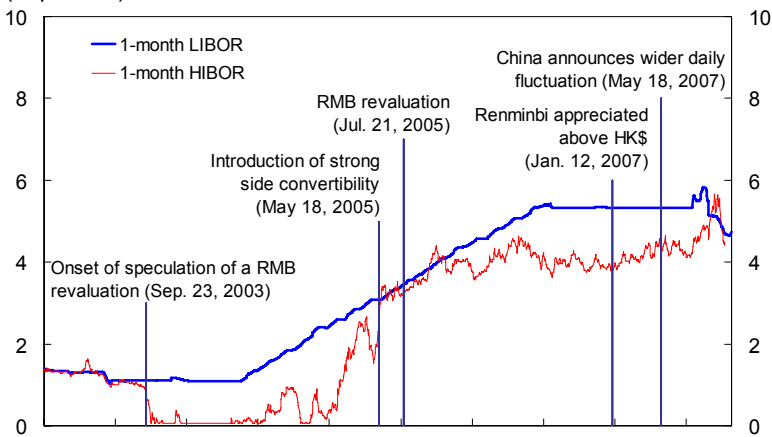

Jan-03 Jul-03 Jan-04 Jul-04 Jan-05 Jul-05 Jan-06 Jul-06 Jan-07 Jul-07
Hong Kong dollar forward rates remained within the trading band through most of 2007.

Spot and Forward Hong Kong Dollar Rates (Hong Kong dollar/U.S. dollar)

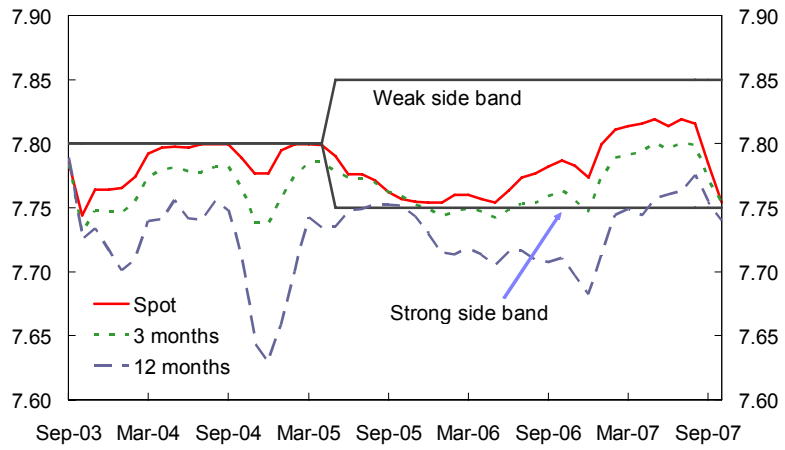

Since then, the aggregate balance has been stable but at a much higher level.

Interbank Operations

(In billions of Hong Kong dollar)

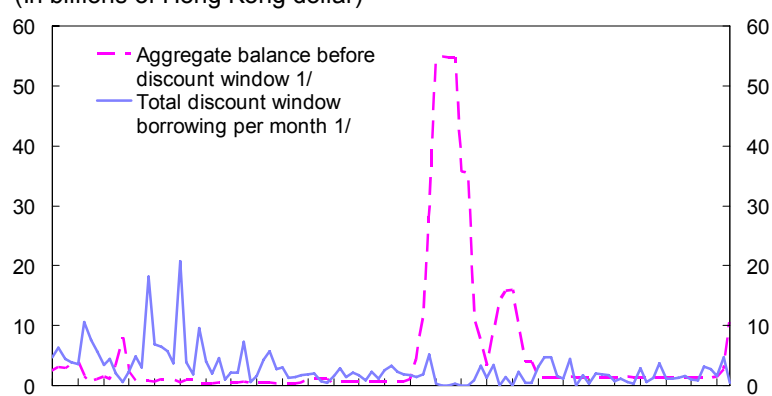

Jan-99 Jan-00 Jan-01 Jan-02 Jan-03 Jan-04 Jan-05 Jan-06 Jan-07 1/ November 2007 data refers to month-to-date as of November 26, 2007

Sources: CEIC Data Co., Ltd.; and Fund staff estimates. 


\section{A. Exchange Rate, Money Markets, and the LERS}

9. Staff reiterated support for the authorities' commitment to the LERS. The May 2005 refinements have fortified the LERS, and the HK\$ has moved inside the trading band with rare interventions by the HKMA. ${ }^{8}$ Given the currency board and open capital account, pressures on the exchange rate typically surface first in money markets. These markets have coped well with periodic stresses, including the large IPO issuances of late last year; speculative pressures when the renminbi-dollar exchange rate crossed the HK\$ linked rate early this year; and the global subprime turmoil this August. However, a number of coincidental events in late-October increased the volatility and uncertainty of short-term liquidity demand for HK\$ that led, ultimately, to a need for intervention. Since the intervention, liquidity in the money market has stabilized, HK\$ interest rates have fallen well below their US\$ counterparts, and the HK\$ has returned inside the trading band.

\section{While agreeing with the authorities that these interventions were passive and} required under the LERS, the staff noted that there might be a need to smooth the operations of the money market. Underlying the events of late-October were uncertainties regarding investor expectations about U.S. and Mainland financial assets and exchange rate movements, capital inflows from the Mainland, and the timing and size of future IPO-related liquidity demand, along with more cautious interbank lending in the wake of the subprime turmoil. ${ }^{9}$ These factors (including the frictions in the money market) appear to have created anomalies in the relationship between the money and foreign exchange markets, i.e., HK\$ interest rates appear to have responded slower to changes in demand for HK\$ than in the past. In the coming months such volatility could very well persist. In light of this, staff suggested that the authorities could consider reinforcing the link between changes in the exchange rate and HK\$ interest rates as well as look to improve the management of liquidity within the financial system. ${ }^{10}$ Doing so could help to avoid further episodic anomalies that in

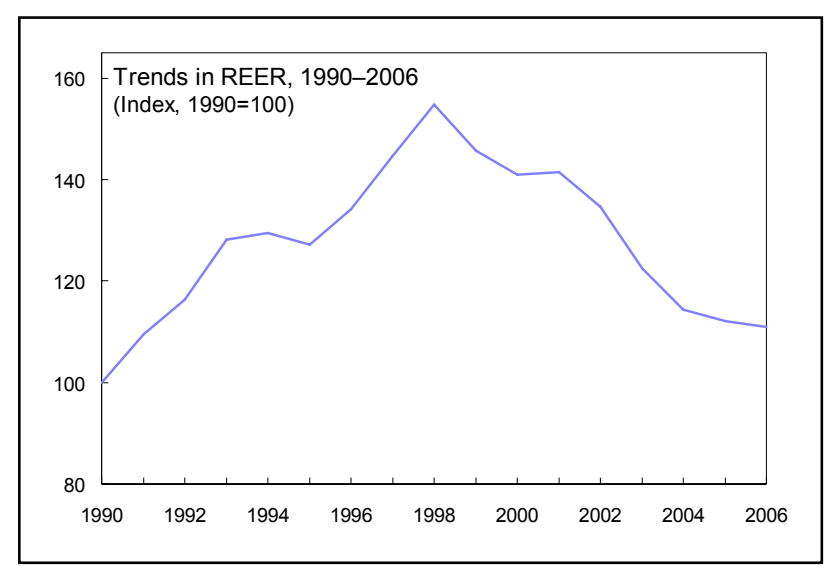

\footnotetext{
${ }^{8}$ Details of the refinements were discussed in the staff report for the 2005 Article IV consultation discussions (IMF Country Report No. 06/50).

${ }^{9}$ While subprime exposure of Hong Kong banks is small, there appears to be a rise in perceived counterparty risk with banks putting in place more cautious interbank lending rules.

${ }^{10} \mathrm{~A}$ box in Chapter I of the selected issues paper show that the gap between HK\$-US\$ interest rates is influenced by a number of variables other than expected exchange rate changes. Among these variables are equity market turnover, IPO activity, and the gap between H.K.-U.S. equity returns.
} 
themselves are a potential source of market speculation about the longevity of the LERS. The authorities agreed that there may be a need to do so. To address money market frictions, the authorities said they were working with banks to improve the recycling of oversubscribed IPO funds and to improve the communication between the interbank desk and the credit department, and are planning to introduce a new mechanism to improve the efficiency of cash settlement of stock trading. However, they noted that normalizing the relationship between the exchange rate and the interest rate, for example, through active intervention would need to be carefully explained to the public otherwise it could be misconstrued as pursuing an active monetary policy against the principles of the LERS. In addition, the authorities were also working on ways to improve the efficiency of the subscription arrangements for equity IPOs.

\section{More importantly, underlying the resilience of the LERS is the demonstrated}

flexibility of Hong Kong SAR's domestic markets. Given the currency board and open markets, adjustment to imbalances and external shocks take place through changes in domestic goods, labor, and asset prices, which, in turn, drive real exchange rate movements. This has been demonstrated several times, for example, in the aftermath of the Asian crisis when the economy adjusted through large goods, asset, and wage deflation. At present, price movements in these markets do not suggest that the real exchange rate is out of line with fundamentals. Inflation is low and is expected to rise only modestly; wage increases lag productivity growth; real estate prices have risen in line with nominal growth; and the price earnings ratio of Hong Kong firms is low, with most of the recent increase in equity prices taking place in Mainland-related stocks.
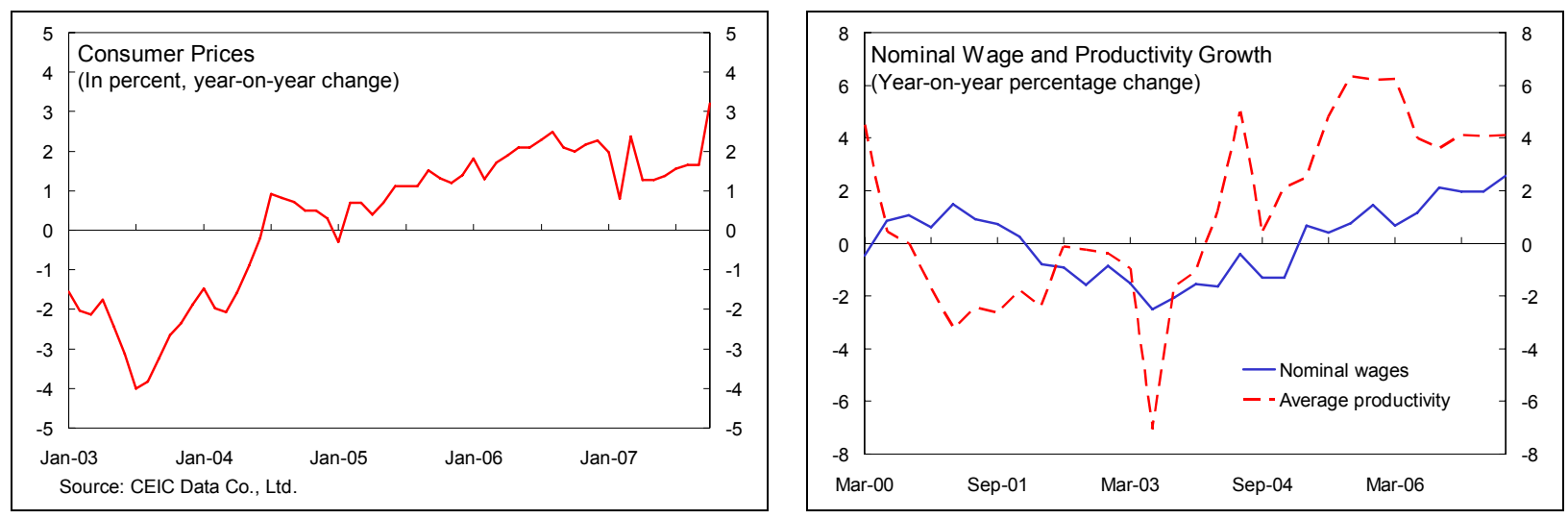

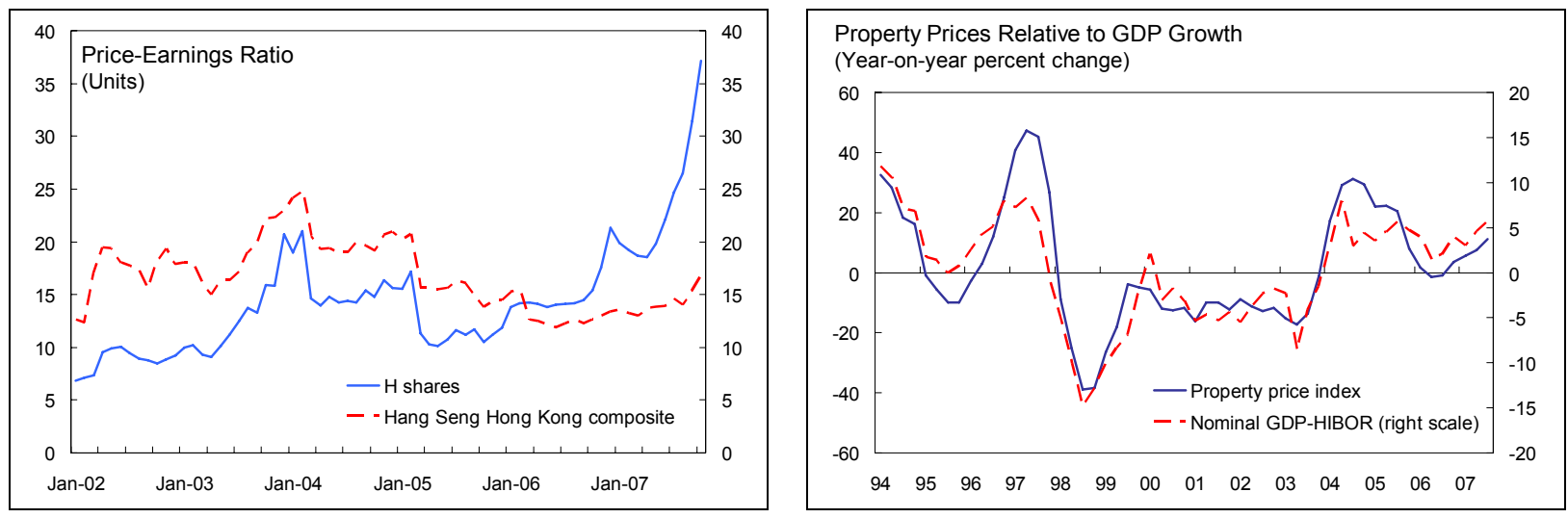

\section{Thus, Hong Kong SAR's market flexibility needs to be safeguarded and}

strengthened. In particular, the authorities' planned implementation of a general

Competition Law in 2008, an initiative staff has long supported, and the establishment of a Competition Commission, should help to strengthen market flexibility. During recent public consultations on the law, some have argued that it would place an onerous regulatory burden on businesses. In this regard, staff suggested that the experiences of other advanced countries with such laws provide lessons as to how to minimize the bureaucratic and regulatory burden while ensuring fair competition. Separately, income inequality has increased over the past decade and has become a concern across many segments of society. Reflecting this concern, the government has commenced preliminary work for a legislated minimum wage covering two low-wage occupations, namely cleaners and security guards. Staff responded that while a minimum wage could form part of a social compact, it needs to be properly designed so that it does not unduly affect either employment or wage flexibility. For this reason, alternative measures, such as expanding in-work benefits including through eligibility requirements and the level of support,

Selected Countries: Gini Coefficients for Income Inequality, 1996-2006

\begin{tabular}{llll}
\hline & 1996 & 2001 & 2006 \\
\hline Hong Kong SAR & & & \\
$\quad$ Original household monthly income & 0.518 & 0.525 & 0.533 \\
$\quad$ Post tax & 0.508 & 0.515 & 0.521 \\
$\quad$ Post tax and transfer & 0.466 & 0.470 & 0.475 \\
$\quad$ Per capita and post tax and transfer & 0.427 & 0.421 & 0.427 \\
Australia 1/ & 0.296 & 0.311 & 0.294 \\
$\quad$ Post tax household income & & 0.513 & 0.510 \\
Canada 2/ & & 0.392 & 0.393 \\
$\quad$ Original household monthly income & & & \\
$\quad$ Post tax and transfer & 0.443 & 0.481 & \\
Singapore 3/ & & 0.440 & \\
$\quad$ Original household monthly income & & 0.437 & \\
$\quad$ Post tax & 0.520 & 0.510 & 0.510 \\
$\quad$ Post tax and transfer & 0.370 & 0.390 & 0.360 \\
United Kingdom 4/ & & & \\
$\quad$ Original household monthly income & & \\
$\quad$ Post tax & 0.455 & 0.466 & 0.450 \\
United States 5/ & & 0.405 & 0.418 \\
$\quad$ Original household monthly income & & \\
$\quad$ Post tax and transfer & & & \\
\hline
\end{tabular}

Sources: 2006 Population By-Census Thematic Report: Household Income Distribution in Hong Kong ; and country authorities.

$1 /$ The three estimates relate to 1995/96, 2000/01, and 2003/04. 2/ The estimates refer to 2001 and 2004. The post tax and transfer estimates are based on after tax income.

3/ The estimates for original household income refer to 1995 and 2000. The post tax estimate refers to 1999 and is based on original income from work after personal tax rebate. The post tax and trasfer estimate also refers to 1999 and is based on original income from work after personal tax rebate; and after recession-related rental, service and conservancy charges and utilities rebates, and public assistance.

4/ The estimates relate to 1995/96, 2000/01, and 2004/05. The post tax estimates are based on post tax income.

5/ the estimates for original household income refer to 1996, 2001, and 2005. The post tax transfer estimates refer to 2003 and 2005 and are based on disposable income.

might be better ways to balance labor market flexibility with wage protection. The authorities agreed to consider these proposals, but noted the significant pressure for such legislation, and 
that the government should not be seen as subsidizing employers through income support payments to low wage earners.

\section{Staff and the authorities also agreed that at present the peg to the US\$ remains}

appropriate. Analysts have often speculated about the ultimate fate of the LERS. Many have argued that with the increased integration of the Hong Kong economy into that of the Mainland, the appropriate peg should be to the renminbi and the not the US\$. However, given the still vast differences in economic development, continued capital controls in China, the nonconvertibility of the renminbi, likely large structural changes in the Mainland's financial markets, and still incomplete financial integration, such a change is only a long run option. ${ }^{11}$ Adjustment to likely increased renminbi flexibility over the medium term, including potentially large appreciation, will continue to rely on changes in the real exchange rate brought about by the SAR's flexible goods, labor, capital, and asset markets. ${ }^{12}$

\section{Hong Kong SAR's economic restructuring has, however, changed its balance of}

payments dynamics. The rise in the current account surplus in recent years largely reflects a secular decline in the domestic investment rate as the economy transformed itself from a manufacturing to a financial and business services hub. Domestic investment was redirected to outward investments that accompanied the relocation of manufacturing and low-end services to the Pearl River Delta. At the same time, domestic saving has remained high in the face
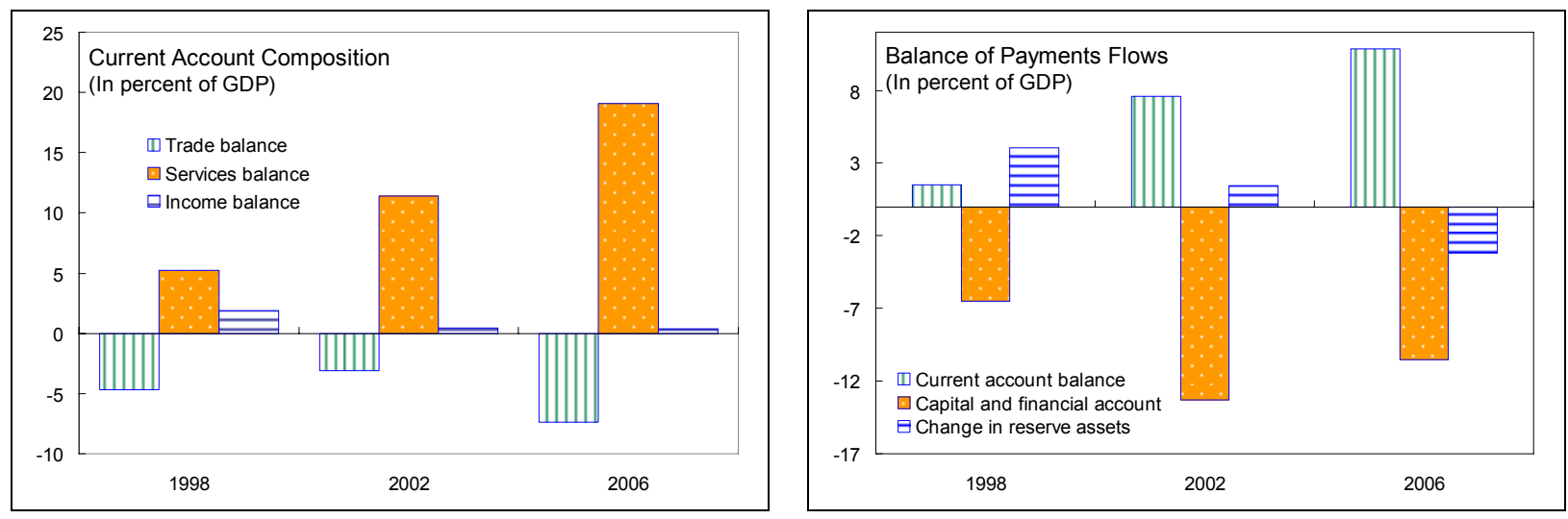

\footnotetext{
${ }^{11}$ While Mainland-related business visibly dominates the Hong Kong economy, it is much less discernible in this data. While this is likely to change as integration with the Mainland deepens and statistics improves, at present aggregate data continue to point to the more dominant role that the U.S. economy and monetary conditions play in the Hong Kong economy. Part of the reason could be the common influence the U.S. economy has on both Hong Kong SAR and the region of China (the Pearl River Delta) to which trade and services linkages are the strongest. For further details see Genberg, Hans, Li-gang Liu and Xiangrong Jin, 2006, "Hong Kong's Economic Integration and Business Cycle Synchronisation with Mainland China and the US," HKMA Research Memorandum 11/2006 (Hong Kong SAR: HKMA).

${ }^{12}$ Given the Mainland's closed capital account, hedging of renminbi risks is largely undertaken through nondeliverable products. These have grown over time covering both exchange rate and interest rate products and market participants considered the extent of coverage to be adequate at present.
} 
of the coming aging of the workforce and higher income volatility arising from the concentration of intermediation services (manufacturing is only 3 percent of value added) and the profit-center nature of the economy. ${ }^{13}$ These two trends have widened the economy's equilibrium current account position. That said, staff expects the current account surplus to narrow in the medium term as infrastructure and other constructionrelated investment, which had been

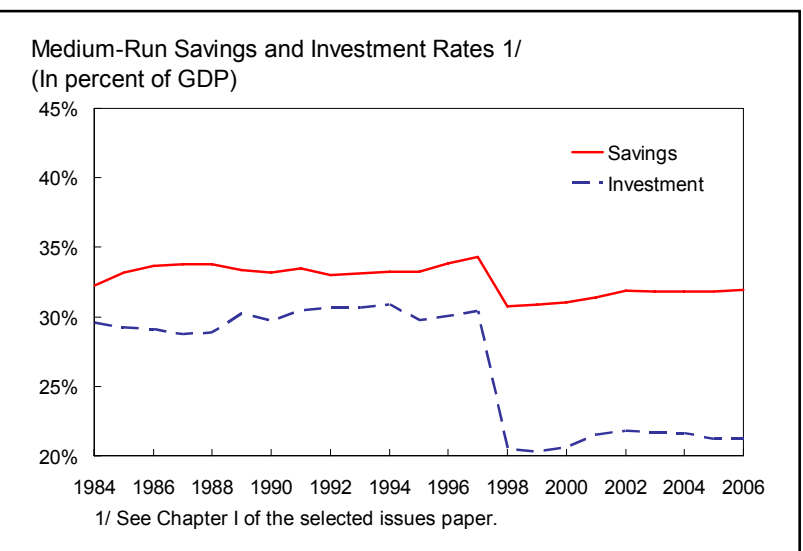

compressed by the increased macroeconomic uncertainty since the Asian crisis, pick up, although not to the pre-crisis levels given the secular decline. ${ }^{14}$ Consequently, any gap between the equilibrium and underlying current account balance is likely to be small.
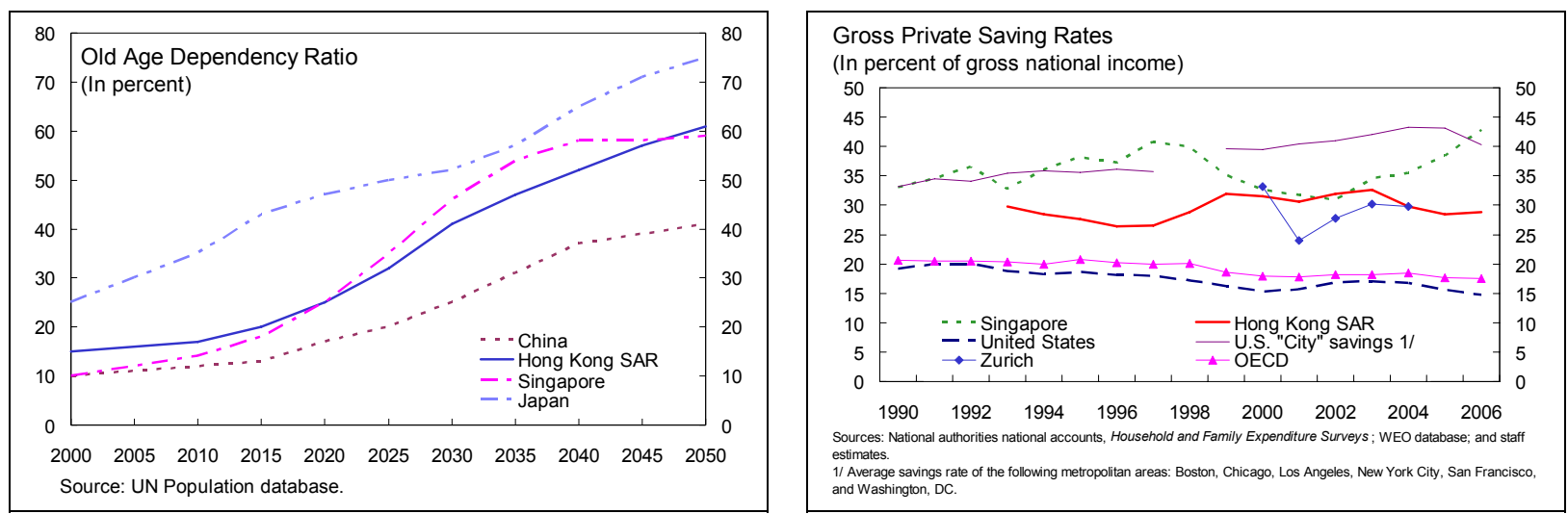

\footnotetext{
${ }^{13}$ While specific circumstances may differ, Hong Kong SAR shares many of these characteristics with other services-based economies, such as those with a large financial center. Typically these are high-income and high-savings economies with relatively high current account surpluses. While it is difficult to pin down the exact reasons, it is likely that the high level and volatility of income and capital flows in these economies have elevated the saving rate, while the low capital intensity of activity and the need to diversify risk have resulted in low domestic investment and large outward investment. In the case of Hong Kong SAR, staff analysis suggests that higher income volatility and aging are significant explanatory factors of structural saving rate, while structural investment is largely driven by volatility. A two-country dynamic stochastic general equilibrium (DSGE) model points to shocks to international financial linkages, domestic monetary conditions, terms of trade, and the cost of capital as the main drivers behind cyclical savings and investment dynamics. For details, see Chapter I of the accompanying selected issues paper.
}

${ }^{14}$ The investment compression of the last decade shows up in standard investment equations that differentiate between the capital intensity of services and manufacturing industries. One such exercise found that Hong Kong SAR investment has been around 4-5 percentage points of GDP below its predicted level in recent years. For further details, see Hori, M., 2007, "Investment Recovery from Financial Crises: A View from Cross-Country Experiences," Chapter II, Thailand: Selected Issues, IMF Country Report No. 07/231, pp. 3-23. 


\section{It is, however, difficult to quantitatively assess the impact of changing balance of} payments dynamics on the real exchange rate. Nonetheless, to provide some indication of the equilibrium value of the HK\$, staff used three standard methods: the macroeconomic balance (MB), the equilibrium real exchange rate (ERER), and the net foreign assets (NFA). Under the first two approaches, the equilibrium value is assessed based on the relative importance of factors that are generally considered important in influencing real exchange movements, typically estimated from their average behavior in comparable economies. ${ }^{15}$ As discussed above, the structure of Hong Kong SAR's economy

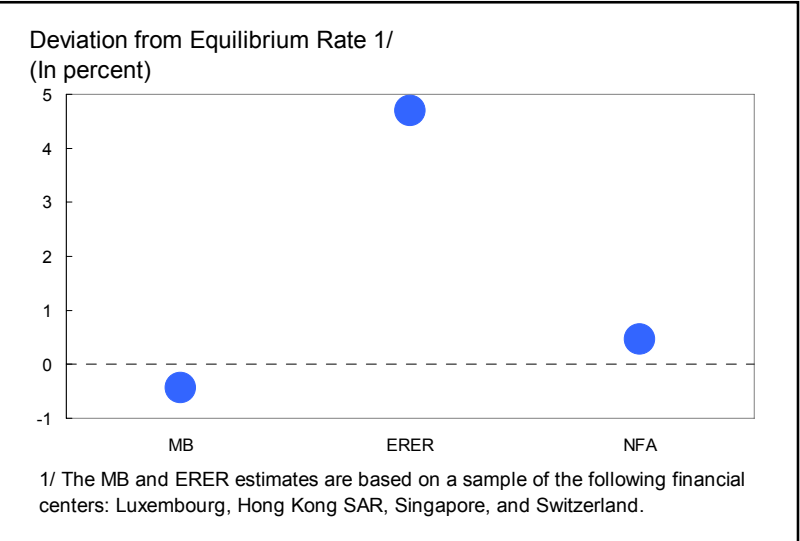
resembles more that of a global city than an advanced economy. But city-level data needed for such exercises are hard to come by, so as an approximation the staff used as comparators advanced economies where value-added from financial activity is large. ${ }^{16}$ These estimates suggest that the deviation of the HK\$ real exchange rate from its equilibrium level ranges from a marginal undervaluation (MB) to a modest overvaluation (ERER). Under the NFA approach, the current account surplus needed to stabilize net foreign assets around its 2006 level suggests that the real exchange rate may be slightly overvalued. In determining the equilibrium exchange rate, the age profile of the population and relative productivity differential with trading partners were significant, while the fiscal balance was not. Changing the comparator economies does not affect the results much as long as the services-based nature of the Hong Kong economy is adequately captured. For example, under the MB approach when the comparator set is extended to a set of 54 advanced and emerging market economies with a dummy for financial centers, the estimated undervaluation is still low, but if the differentiation of financial centers is dropped, the undervaluation increases. The authorities' noted that their estimates based on similar approaches were in broad agreement

\footnotetext{
${ }^{15}$ Under the MB approach, the gap between the underlying and equilibrium current account balances is estimated and deviation of the real exchange rate from its fair value determined as the amount by which the rate has to change to close this gap. In estimating the equilibrium current account, old-age dependency, the fiscal balance, relative growth (with respect to trading partners) and the lagged net foreign asset were used as is standard. Under the ERER approach, the equilibrium real exchange rate is estimated as being determined by productivity differential (with trading partners), terms of trade, public consumption, and net foreign assets.
}

${ }^{16}$ The base comparator economies are Hong Kong SAR, Singapore, Luxembourg, and Switzerland. To check the robustness of the results, the comparator group was extended to also include other Asian economiesAustralia, China, India, Japan, Korea, Malaysia, New Zealand, the Philippines, and Taiwan POC — and to the larger samples used in the IMF's CGER exercise. 
with these results. ${ }^{17}$ Taking all this together, the real exchange rate is in line with fundamentals. Nonetheless, staff and the authorities agreed that, because these estimates are based on simplified economic structures and have large estimation errors, they should be treated as only indicators of the Hong Kong dollar's equilibrium value.
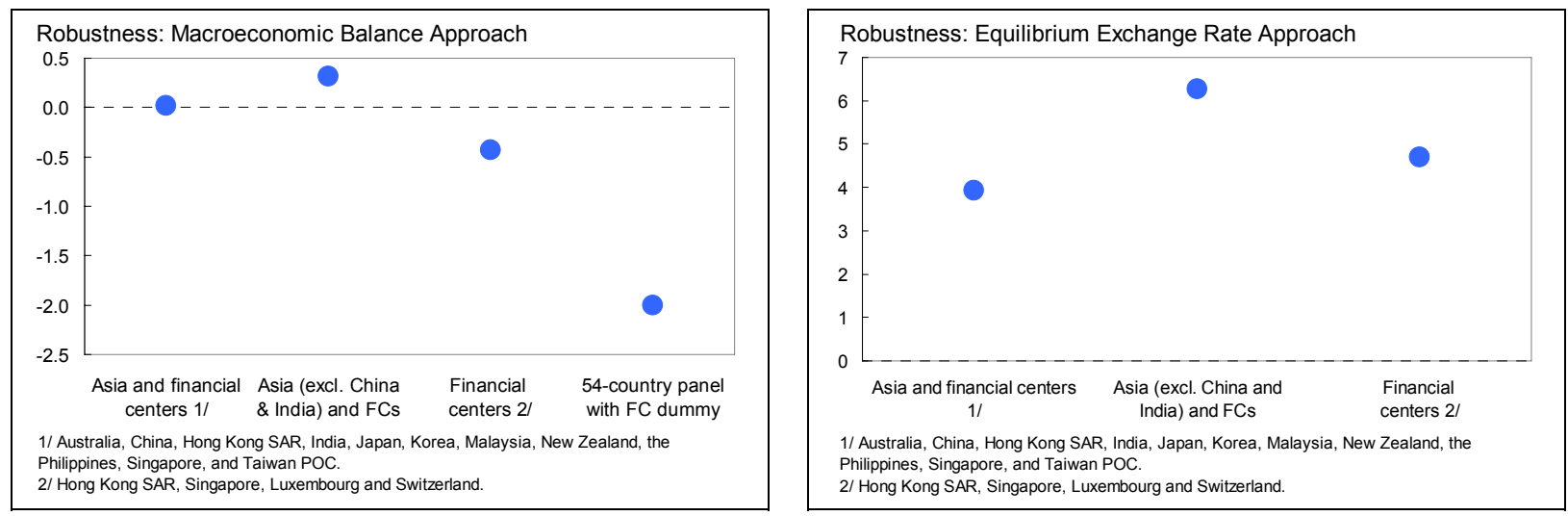

16. Nonprice competitiveness factors are also important for the success of the Hong Kong financial center. As availability of human capital is a key factor, the authorities have focused on raising the standard of education. In addition, they are also attending to reducing regulatory burden and on cutting pollution, which has surfaced in recent years as a major concern. ${ }^{18}$

\section{B. Financial Market Development and Competitiveness}

17. Hong Kong SAR's financial center remains robust. While there have been fewer headline-grabbing IPOs than in 2006, the number of such issues by Mainland and domestic firms has increased. In the first three quarters, total equity funds raised was significantly higher than in the corresponding period last year, although fundraising for the year as a whole will likely be lower given the very large IPOs in late-2006. The authorities noted that subprime exposures seemed to be low, and while these exposures may be self reported, they were content with the degree of disclosure. Hong Kong SAR banks have also continued to expand their Mainland-related activities, with several seeking to go beyond their strategic interests in Mainland banks and branches, by establishing subsidiaries. ${ }^{19}$ Mainland-related

\footnotetext{
${ }^{17}$ For the authorities' estimates, see F. Leung and P. Ng, "Is the Hong Kong Dollar Real Exchange Rate Misaligned?," HKMA Working Paper 21/2007 (December).

${ }^{18}$ See Syed, Murtaza, "Competitiveness: Trends and Prospects," Chapter II in People's Republic of ChinaHong Kong Special Administrative Region: Selected Issues, IMF Country Report No. 07/4 (Washington: International Monetary Fund).

${ }^{19}$ The fourth supplementary Closer Economic Partnership Agreement (CEPA IV) arrangement between the Mainland and Hong Kong SAR includes a number of provisions (including new asset requirements and application procedures) to facilitate the expansion of Hong Kong banks on the Mainland, as well as increasing the outward mobility of Mainland banks into the SAR.
} 
lending now accounts for 20 percent of total loans, but the authorities pointed out that much of these loans are to long-standing customers and are unlikely to significantly increase banks' credit risk. Hong Kong SAR's funds management sector has also grown rapidly in recent years, with a steadily growing share of these funds being managed within the SAR. ${ }^{20}$
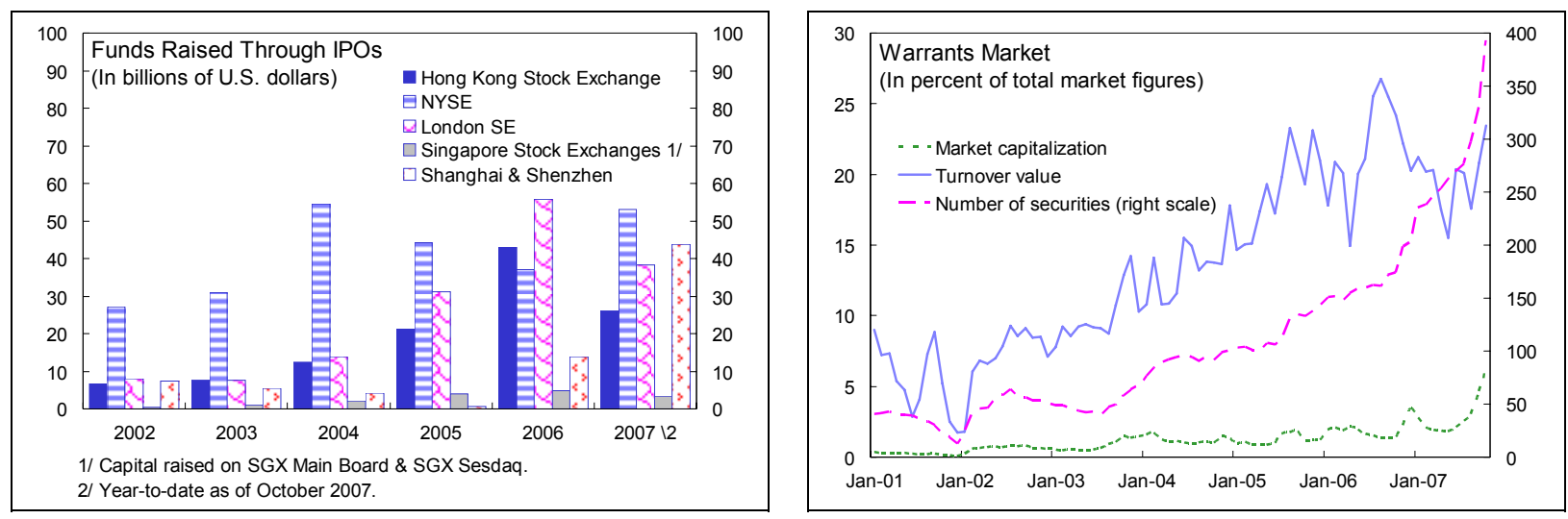

18. There was broad agreement among the authorities, market participants and the staff that the financial center's longer-term future is intimately linked with Mainland intermediation. Recognizing the importance of integration, the authorities published a focus group on financial services (FG) report in January this year that put forward a number of proposals to expand the role Hong Kong SAR could play in helping the Mainland open its capital account in an orderly manner as sought under China's $11^{\text {th }}$ Five-Year Plan. Two aspects of the initiatives are under active consideration: finding appropriate means to enhance linkages between the financial markets of Hong Kong SAR and the Mainland, and allowing Mainland individuals to invest in Hong Kong markets. On the latter proposal, the authorities and market participants both saw the present delay in the proposal to allow Mainland individuals to invest in Hong Kong markets as being temporary. Separately, the Mainland's expansion of its qualified domestic institutional investor (QDII) program should also benefit the Hong Kong financial center. These schemes could facilitate at least partial arbitrage between the $\mathrm{A}$ and $\mathrm{H}$ shares and, while some overshooting could occur, the price differential would narrow. ${ }^{21}$ Supplement IV to CEPA also allows Mainland fund managers to establish subsidiaries in Hong Kong SAR, which in addition to deepening integration, also could create an international springboard for them.

\footnotetext{
${ }^{20}$ Chapter II of the selected issues paper discusses Hong Kong SAR's key role in intermediating Asia's financial flows and how this could evolve going forward.

${ }^{21}$ At present, Mainland equities trade at a premium compared with those listed in Hong Kong SAR. As the Hong Kong equity market competes with many other investment products and is freely open to global investors, the premium in the $\mathrm{A}$-share market reflects its limited market depth and lack of alternative investment opportunities.
} 
19. Announced early this year, renminbi bond issuance in Hong Kong SAR began in June. Three Mainland banks have so far issued bonds, raising around RMB 10 billion, in generally well received issues. ${ }^{22}$ However, as currently configured, the scope of this scheme is limited to the renminbi bank deposits held in the SAR. Staff suggested that expanding renminbi bonds issuance to nonfinancial corporates and allowing Mainland investors to purchase and trade these bonds would be beneficial to both economies. Such an expansion would not involve any additional capital account opening in China as trading would be entirely in renminbi and it would allow Mainland firms and investors to benefit from Hong Kong SAR's listing and investor protection rules. The authorities noted their interest in expanding this

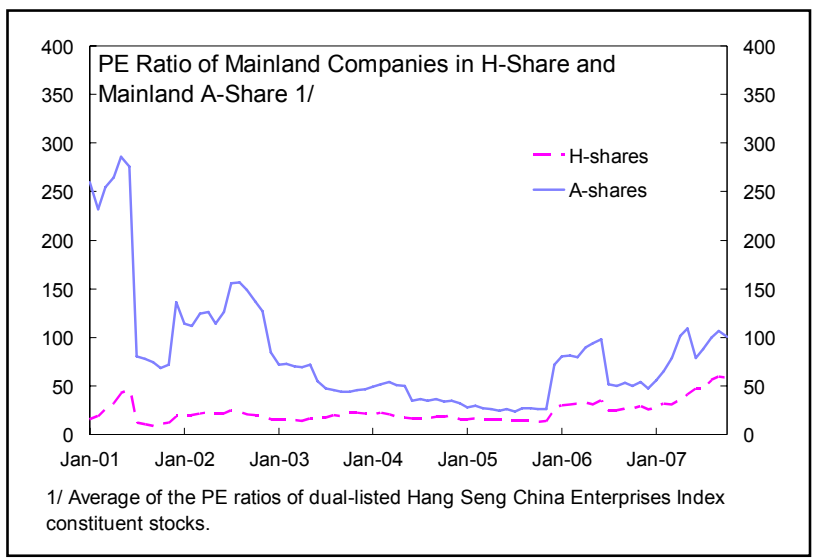
business in collaboration with the Mainland authorities.

\section{The authorities consider safeguarding Hong Kong SAR's first-mover advantage} to be vital in keeping the financial center attractive to Mainland investors. This could be advanced by expanding the products available to investors, including through increased cross listing of equities of other jurisdictions and expanding into new businesses, such as commodities and emissions-related derivatives and annuities. The authorities noted that the exchange's listing committee has approved England, Australia, and Canada (British Columbia) as acceptable jurisdictions for cross listing, and are reviewing relevant legislation to explore the feasibility of cross listing through depository receipts. The authorities are also keenly studying the feasibility of offering Islamic financial products. ${ }^{23}$

\section{That said, both the authorities and the staff agreed that ensuring continued} financial stability would be essential to the financial sector's competitiveness. The authorities noted that the implementation of Basel II this year has gone smoothly, with most authorized institutions using the standardized approach initially. The HKMA will continue to assess the institutions' readiness to adopt more advanced model-based approaches to risk calculation. Close market surveillance and coordination between Hong Kong SAR and Mainland supervisors continue across banking, securities and insurance sectors under various memoranda of understanding (MOU) and legislation. Most recently, the coordination was enhanced with the China Securities Regulatory Commission (CSRC) becoming a signatory to

\footnotetext{
${ }^{22}$ Settlement of these retail issues has been smooth given Hong Kong SAR's RTGS system for renminbi bonds, but there does not yet appear to be any significant secondary market activity.

${ }^{23}$ Recently, the Security and Futures Commission approved the first retail Islamic Fund.
} 
the IOSCO MOU. The establishment of the Financial Reporting Council this July should safeguard the quality of financial reports. The proposed establishment of an independent insurance regulator, which is currently under consideration, should also bring the institutional arrangement better in line with the international regulatory trend. Multifaceted improvements to the AML/CFT regime, including through new legislative measures, have also recently been put in place to improve verification and record keeping and increase sanctions, with additional legislative changes planned. That said, staff noted that the rapid rise in valuation and turnover of equities, related structured products and derivatives, and margin financing, called for continued close monitoring of cross-market risks and the potential for spillovers, especially given heightened global financial market uncertainty, which tended to increase correlation across markets. The authorities agreed on the need for increased vigilance and pointed out that the increased coordination among Hong Kong SAR regulators should help to detect early signs of stress. Nonetheless, they noted that because of this increased vigilance and coordination among regulators, the potential impact of increased financial market turbulence would likely be limited.

\section{Near- and Medium-Term Fiscal Policy}

\section{The current fiscal stance appears appropriate given the moderation in growth,} and is likely to remain supportive over the medium term. Following a surplus of 4 percent of GDP last year, a surplus of around $3-3 \frac{1}{2}$ percent of GDP is expected this year, around twice the budgeted target. The over performance reflects stronger than expected stamp duty and land sales revenue and some expenditure restraint, and comes despite some one-off measures. The Chief Executive's October Policy Address also announced a reduction in profit and salaries taxes and a refocusing on infrastructure investment, which could enhance competitiveness provided the longer-term fiscal challenges discussed below are addressed. $^{24}$

\section{Staff welcomed the new initiatives to tackle the high volatility of government} revenue. Staff has previously suggested that Hong Kong SAR adopt a longer-term fiscal strategy with an appropriately targeted level of fiscal reserves - reflecting revenue volatility - to provide assurance that Hong Kong SAR's traditional low-tax environment would be preserved in the event of large unanticipated shocks to public finances. Effective from April 1, 2007, the government has revised the investment income arrangement for fiscal reserves with the Exchange Fund. Under the new arrangement, the return on fiscal reserves placed with the Exchange Fund will be calculated on the basis of the average rate of return of

\footnotetext{
${ }^{24}$ The standard rate of salaries tax is planned to be cut to 15 percent from 16 percent, and the profits tax rate from 17.5 percent to 16.5 percent for FY 2008/09, costing about 2 percent of revenue. Public spending will rise due to the infrastructure projects, however, its timing and extent will depend on how they are implemented and the scope for private sector partnership. While some of these investments could begin as early as 2009, most would be spread out beyond 2010, but the government is committed to keep public spending below 20 percent of GDP.
} 
the fund's investment portfolio over the past six years. ${ }^{25}$ The budget also forecast fiscal reserves to increase to around 30 percent of GDP over the medium term, consistent with past staff estimates of risks associated with historical revenue volatility.

24. However, medium-term fiscal challenges remain. Despite recent policy changes, revenue remains volatile and longer-term aging-related fiscal pressures loom. The government's tax reform consultation that ended in March built public awareness of the need to broaden the narrow tax base, but failed to build sufficient support for the proposed goods and services tax. While staff has long supported such a tax to smooth tax revenue, this hiatus might be a good opportunity to explore other options, such as expanding the base of the salaries tax. ${ }^{26}$ To address potential aging-related fiscal pressures, the government is expected to propose reforms to healthcare financing in early 2008. Staff estimates that age-related household spending could rise by as much as 8 percent of GDP. The proposals are likely to include greater private provision, insurance, and

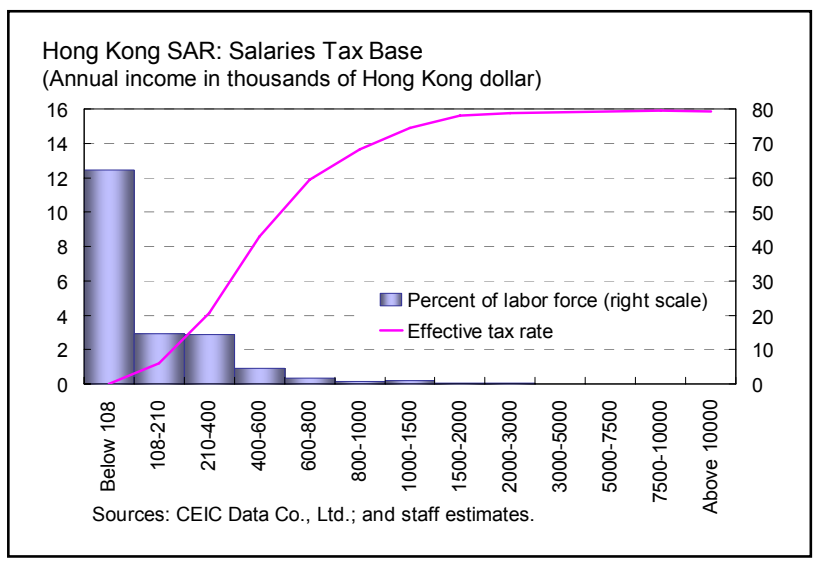
compulsory medical savings. Staff supports these initiatives and suggested that measures (including tax-related) should be considered to encourage a move to broad-based medical insurance and savings plans for old-age coverage. Given such considerations, it might be appropriate to reconsider the scope and timing of the proposed cuts in salaries and profits tax in the context of the new health-care financing mechanisms. The authorities noted that they would carefully consider these options in finalizing the health reforms.

\footnotetext{
${ }^{25}$ As the new arrangement replaced one where the government earns an income on its fiscal reserves placed with the Exchange Fund at a rate equal to that of the entire fund, the new arrangement is not expected to generate substantially different revenue over the longer term.

${ }^{26}$ With only around one third of earners paying salaries tax, expanding the base could provide significantly broader and more stable coverage. The 2001 and 2004 FAD technical assistance reports argued that since Hong Kong SAR does not tax interest income, capital gains or investment expenditure, the combined salaries and corporate income taxes could come close to a GST.
} 
Figure 3. Hong Kong SAR: Fiscal Developments

The budget surplus rose significantly...

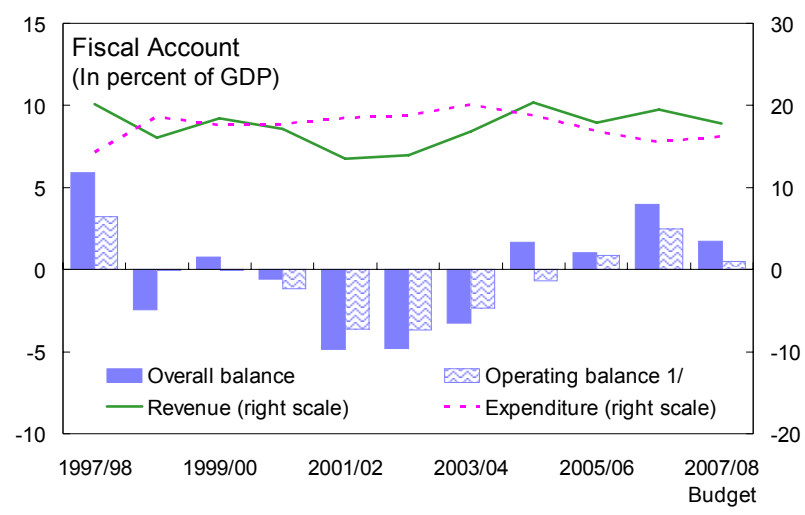

1/ Operating balance, as defined by the authorities, is akin to the current balance.

....and strong revenue...

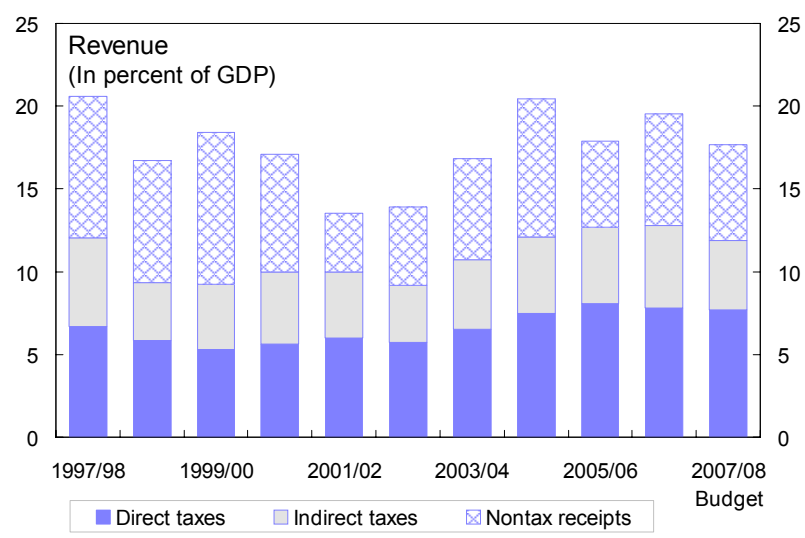

Revenue volatility remains high, driven by nontax income.

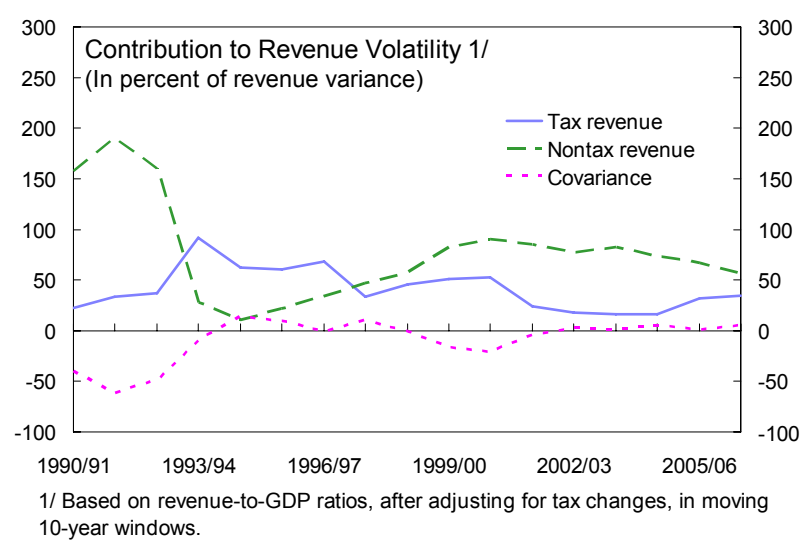

....reflecting restrained spending...

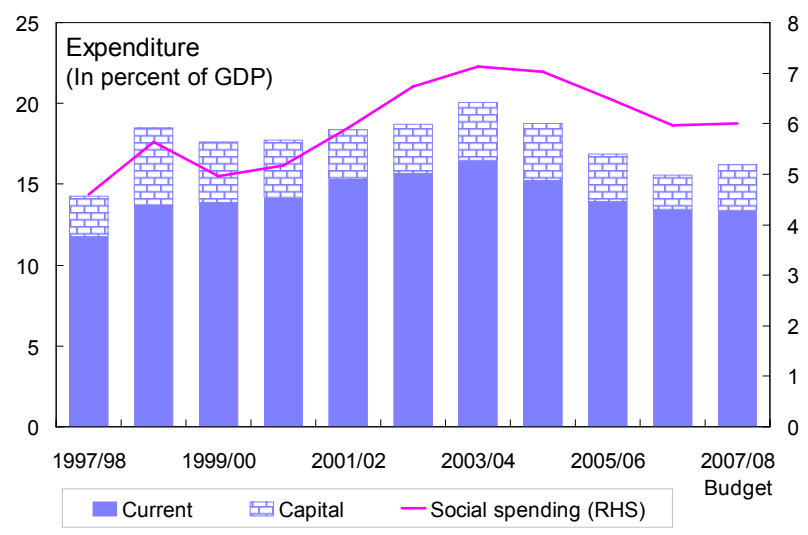

...boosting fiscal reserves.

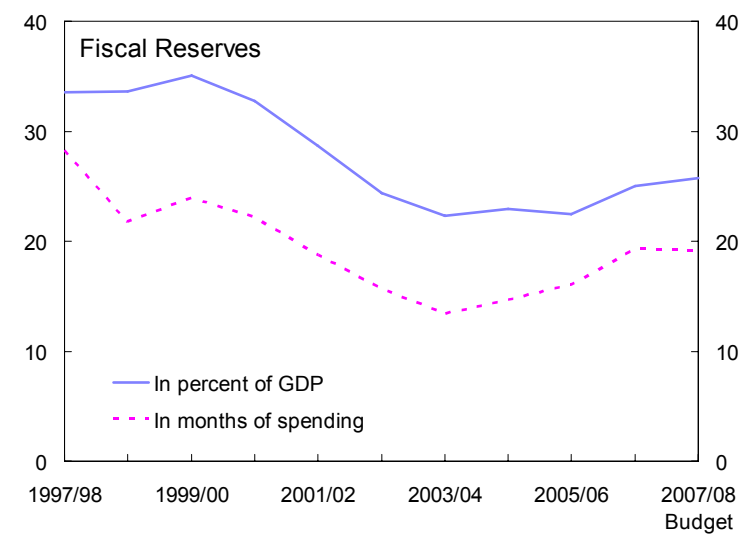

Fiscal policy moved to a more neutral setting this year.

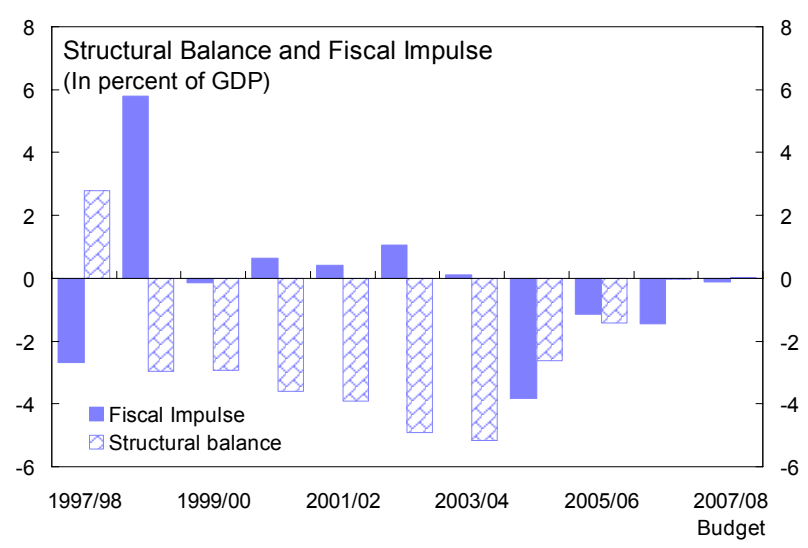

Sources: CEIC Data Co., Ltd.; and Fund staff estimates. 


\section{StAFF Appraisal}

\section{After four years of rapid growth, the pace of growth is expected to moderate.}

Domestic demand has increasingly been the key driver, which has led to an expansion in the merchandise trade deficit and narrowing of the current account surplus. Job creation has increased while inflation is set to pick up with the ending of some budget measures, but will likely remain moderate. Despite, the recent subprime turmoil, financial institutions, households, and corporates remain healthy. Nonetheless, growth is expected to moderate to below 5 percent in 2008, in line with weaker U.S. and European demand. Over the medium term, much will depend on how well the SAR deepens its role in Mainland intermediation and manages competitive pressures from other regional financial centers. If this goes well, growth could average around 5 percent.

\section{Staff reiterates its support for the authorities' commitment for the LERS.}

Through much of the last two years the Hong Kong dollar floated within the trading band with only rare interventions, withstanding periods of often significant speculative pressures. Recent intervention reflected a confluence of factors that drove up short-term demand for liquidity and frictions in the money market that led to temporary anomalies in its functioning. Consequently, addressing these frictions to limit such occurrences in the future is a priority, as these anomalies could become a source of speculation if they persist. Nonetheless, the generally smooth operation of the LERS during this period of stress underscores the system's strength. Also, both qualitative and quantitative evidence suggests that the real value of the Hong Kong dollar is in line with fundamentals.

\section{The authorities are aware of the central importance of Hong Kong SAR's} traditional strengths - market flexibility and sound governance and institutions - to its ongoing success. The authorities are pursuing a general competition law that should strengthen market flexibility, especially in nontradables. Measures aimed at balancing wage flexibility and worker protection could consider expanding in-work benefits rather than legislating a minimum wage; labor market flexibility plays a pivotal role in maintaining the resilience of the currency board and supporting the economy's ability to adjust to external shocks. The smooth implementation of Basel II, enhanced AML/CFT compliance, and establishment of the Financial Reporting Council has improved Hong Kong SAR's already strong governance and supervisory regimes.

\section{The future of Hong Kong SAR's financial center is intimately linked with Hong} Kong SAR's expanding role in Mainland intermediation. The authorities recognize this, and have been proactive in seeking ways for the SAR's developed financial platform to benefit the Mainland. Listing of Hong Kong exchange traded funds, and investment by Mainland individuals in Hong Kong markets, along with expansion of China's QDII program could be the key steps in this direction. Together with this deepening integration, cross-border coordination of Mainland and Hong Kong regulators has also increased. Nonetheless, for Hong Kong SAR to safeguard its current advantages, as well as diversify its business base, expanding the range and type of products on offer will be important. 
29. While Hong Kong SAR's current fiscal stance is appropriate, some fiscal challenges remain. In particular, the continued revenue volatility and potentially steep rises in aging-related spending require attention. While the government's new investment income arrangement is a welcome step to limit volatility, there remains a need to broaden the tax base. The government is wisely seeking to address aging-related spending pressures through reforms to healthcare financing and provision. It may be appropriate to link the scope and timing of proposed tax cuts with these pressing fiscal reforms.

30. It is recommended that the next Article IV consultation discussions take place on the standard 12-month cycle. 
Table 1. Hong Kong SAR: Selected Economic and Financial Indicators, 2004-08 1/

Nominal GDP (2006): US\$189.8 billion

Main domestic goods exports (percent of total, 2006): textiles and clothing (54); electronic products (34)

GDP per capita (2006): US $\$ 27,700$

Unemployment rate (2006): 4.8 percent

Net FDI (2006): US $\$-0.6$ billion

Public debt (2006): 1.5 percent of GDP

Foreign public debt (2006): 0.9 percent of GDP

\begin{tabular}{|c|c|c|c|c|c|c|c|c|}
\hline & \multirow[t]{2}{*}{2004} & \multirow[t]{2}{*}{2005} & \multirow[t]{2}{*}{2006} & \multicolumn{3}{|c|}{2007} & \multirow{2}{*}{\multicolumn{2}{|c|}{$\begin{array}{ll}2007 & 2008 \\
\text { Staff proj. }\end{array}$}} \\
\hline & & & & Q1 & Q2 & $\overline{\text { Q3 }}$ & & \\
\hline Real GDP (percent change) & 8.5 & 7.1 & 6.8 & 5.6 & 6.6 & 6.2 & 6.0 & 4.6 \\
\hline \multicolumn{9}{|l|}{ Contribution } \\
\hline Domestic demand & 4.7 & 1.5 & 5.1 & 4.5 & 7.4 & 6.9 & 6.1 & 5.1 \\
\hline Private consumption & 4.3 & 1.8 & 3.4 & 2.8 & 3.5 & 5.3 & 3.8 & 3.2 \\
\hline Government consumption & 0.1 & -0.3 & 0.0 & 0.2 & 0.2 & 0.1 & 0.4 & 0.2 \\
\hline Gross fixed capital formation & 0.6 & 0.9 & 1.3 & 0.6 & 2.2 & 0.4 & 1.9 & 1.7 \\
\hline Inventories & -0.1 & -1.0 & 0.3 & 0.8 & 1.6 & 1.0 & 0.0 & 0.0 \\
\hline Net exports & 3.5 & 5.6 & 1.7 & 1.1 & -0.8 & -0.7 & 0.0 & -0.5 \\
\hline \multicolumn{9}{|l|}{ Inflation (percent change) } \\
\hline Consumer prices & -0.4 & 1.0 & 2.0 & 1.7 & 1.3 & 1.6 & 2.2 & 3.7 \\
\hline GDP deflator & -3.5 & -0.1 & -0.1 & 1.2 & 1.9 & 3.4 & 2.0 & 2.3 \\
\hline Employment (percent change) & 2.5 & 2.0 & 2.1 & 2.5 & 3.4 & 2.0 & 1.7 & 1.0 \\
\hline Unemployment rate (percent, period average) & 6.8 & 5.6 & 4.8 & 4.3 & 4.2 & 4.1 & 4.1 & 4.0 \\
\hline Real wages & -1.2 & -0.4 & -0.3 & -0.2 & 1.8 & $\ldots$ & $\ldots$ & $\ldots$ \\
\hline \multicolumn{9}{|l|}{ Government budget (percent of GDP) 2/ } \\
\hline Revenue & 18.4 & 17.9 & 19.5 & $\ldots$ & $\ldots$ & $\ldots$ & 18.4 & 18.9 \\
\hline Expenditure & 18.8 & 16.9 & 15.4 & $\ldots$ & $\ldots$ & $\ldots$ & 15.1 & 15.8 \\
\hline Consolidated budget balance & -0.3 & 1.0 & 4.0 & $\ldots$ & $\ldots$ & $\ldots$ & 3.3 & 2.9 \\
\hline Fiscal reserves as of March 31 & 22.9 & 22.5 & 25.0 & $\ldots$ & $\ldots$ & $\ldots$ & 27.3 & 27.1 \\
\hline \multicolumn{9}{|l|}{ Money and credit (percent change, end-period) } \\
\hline Narrow money (M1) & 17.2 & -10.3 & 13.1 & 21.7 & 43.8 & 34.6 & $\ldots$ & $\ldots$ \\
\hline Broad money (M3) & 8.6 & 5.2 & 15.5 & 16.5 & 20.5 & 22.3 & $\ldots$ & $\ldots$ \\
\hline Loans for use in Hong Kong SAR & 4.9 & 7.7 & 2.3 & 10.9 & 14.9 & 20.2 & $\ldots$ & $\ldots$ \\
\hline \multicolumn{9}{|l|}{ Interest rates (percent, end-period) } \\
\hline Best lending rate & 5.0 & 7.8 & 7.8 & 7.8 & 7.8 & 7.5 & $\ldots$ & $\ldots$ \\
\hline Three-month HIBOR & 0.3 & 4.2 & 3.8 & 4.1 & 4.4 & 5.1 & $\ldots$ & $\ldots$ \\
\hline \multicolumn{9}{|l|}{ Asset prices } \\
\hline Hang Seng stock index (period average, 1964=100) & 12,988 & 14,402 & 17,118 & 19,853 & 20,909 & 24,771 & $\ldots$ & $\ldots$ \\
\hline Hang Seng stock index (percent change) & 25.5 & 10.9 & 18.9 & 25.4 & 28.6 & 43.2 & $\ldots$ & $\ldots$ \\
\hline Residential property prices (percent change) & 26.6 & 17.9 & 0.8 & 5.6 & 7.6 & 11.2 & $\ldots$ & $\ldots$ \\
\hline \multicolumn{9}{|l|}{ Merchandise trade (percent change) } \\
\hline Export volume & 14.9 & 10.4 & 9.3 & 6.6 & 10.1 & 6.4 & 6.2 & 5.9 \\
\hline Import volume & 13.7 & 8.0 & 9.2 & 7.1 & 11.6 & 8.3 & 7.3 & 7.2 \\
\hline \multicolumn{9}{|l|}{ External balances (percent of GDP) } \\
\hline Merchandise trade balance & -5.6 & -4.3 & -7.4 & -9.3 & -12.2 & -6.6 & -10.6 & -13.7 \\
\hline Domestic exports & 9.8 & 9.9 & 9.4 & 6.4 & 7.9 & 7.5 & 9.9 & 9.7 \\
\hline Re-exports & 147.1 & 153.0 & 157.9 & 152.5 & 165.3 & 167.0 & 167.7 & 169.9 \\
\hline Imports & 162.5 & 167.1 & 174.7 & 168.1 & 185.4 & 181.1 & 188.2 & 193.3 \\
\hline Current account & 9.5 & 11.4 & 10.6 & 16.4 & 6.6 & $\ldots$ & 10.7 & 8.6 \\
\hline \multicolumn{9}{|l|}{ Foreign exchange reserves $3 /$} \\
\hline In billions of U.S. dollars, end-of-period & 123.6 & 124.3 & 133.2 & 135.4 & 136.3 & 140.9 & 153.7 & 160.5 \\
\hline In months of retained imports & 21.1 & 19.8 & 18.6 & 18.9 & 18.6 & 18.8 & 17.4 & 15.8 \\
\hline In percent of broad money (M3) & 22.9 & 21.9 & 20.4 & 20.0 & 18.9 & 18.3 & $\ldots$ & $\ldots$ \\
\hline \multicolumn{9}{|l|}{ Exchange rate } \\
\hline Linked rate (fixed) & & & & $80 /$ US $\$ 1$ & & & & \\
\hline Market rate (HK\$/US\$1, period average) & 7.788 & 7.777 & 7.768 & 7.807 & 7.816 & 7.806 & $\ldots$ & $\ldots$ \\
\hline Real effective rate (period average, $2000=100$ ) & 81.2 & 79.5 & 78.7 & 76.3 & 74.9 & $\ldots$ & $\ldots$ & $\ldots$ \\
\hline
\end{tabular}

Sources: Data provided by the Hong Kong SAR authorities; and staff estimates and projections.

$1 /$ Unless otherwise stated, all growth rates are for year-on-year.

2/ Authorities' FY 2007/08 budget estimates.

3/ Includes Land Fund assets from 1997 (US\$17.5 billion at end-1997) 
Table 2. Hong Kong SAR: Consolidated Government Account, 2004/05-2011/12 1/

(In percent of GDP, unless otherwise stated)

2004/05 2005/06 2006/07 2006/07 2007/08 2007/08 2008/09 2009/10 2010/11 2011/12

Actual Actual Budget Prel. Budget Proj. Budget Budget Budget Budget

\begin{tabular}{|c|c|c|c|c|c|c|c|c|c|c|}
\hline Revenue & 18.4 & 17.9 & 17.7 & 19.5 & 17.8 & 18.4 & 18.9 & 18.6 & 18.2 & 18.2 \\
\hline Taxes & 12.1 & 12.7 & 11.9 & 12.8 & 11.6 & $\ldots$ & $\ldots$ & $\ldots$ & $\ldots$ & $\ldots$ \\
\hline Direct taxes & 7.5 & 8.1 & 7.7 & 7.8 & 7.3 & $\ldots$ & $\ldots$ & $\ldots$ & $\ldots$ & $\ldots$ \\
\hline \multicolumn{11}{|l|}{ Of which: } \\
\hline Salaries tax & 2.6 & 2.7 & 2.6 & 2.6 & 1.9 & $\ldots$ & $\ldots$ & $\ldots$ & $\ldots$ & $\ldots$ \\
\hline Profits tax & 4.5 & 5.0 & 4.9 & 4.9 & 5.0 & $\ldots$ & $\ldots$ & $\ldots$ & $\ldots$ & $\ldots$ \\
\hline Indirect taxes & 4.6 & 4.6 & 4.20 & 5.0 & 4.3 & $\ldots$ & $\ldots$ & $\ldots$ & $\ldots$ & $\ldots$ \\
\hline $\begin{array}{l}\text { Nontax } \\
\quad \text { Of which: }\end{array}$ & 6.3 & 5.2 & 5.8 & 6.8 & 6.2 & $\ldots$ & $\ldots$ & $\ldots$ & $\ldots$ & $\ldots$ \\
\hline Land premium & 2.5 & 2.1 & 2.1 & 2.5 & 2.5 & $\ldots$ & $\ldots$ & $\ldots$ & $\ldots$ & $\ldots$ \\
\hline Investment income & 1.1 & 0.7 & 1.3 & 2.0 & 1.7 & 1.7 & 2.1 & 2.1 & 1.8 & 1.8 \\
\hline Expenditure & 18.8 & 16.9 & 17.2 & 15.4 & 16.2 & 15.1 & 15.8 & 16.0 & 15.8 & 15.2 \\
\hline Current & 14.9 & 13.5 & 13.8 & 12.9 & 13.4 & 13.0 & $\ldots$ & $\ldots$ & $\ldots$ & $\ldots$ \\
\hline Capital & 3.9 & 3.3 & 3.4 & 2.5 & 2.8 & 2.2 & $\ldots$ & $\ldots$ & $\ldots$ & $\ldots$ \\
\hline Overall balance & -0.3 & 1.0 & 0.4 & 4.0 & 1.7 & 3.3 & 2.9 & 2.4 & 2.5 & 3.0 \\
\hline \multicolumn{11}{|l|}{ Memorandum items: } \\
\hline Operating balance $2 /$ & -0.7 & 0.9 & 0.0 & 2.5 & 0.5 & 1.4 & 1.4 & 1.7 & 1.8 & 2.1 \\
\hline Primary balance $3 /$ & 0.5 & 0.3 & -1.5 & 2.0 & 0.0 & 1.6 & 1.0 & 0.6 & 0.7 & 1.3 \\
\hline Structural balance 4/ & -2.6 & -1.4 & -3.0 & 0.0 & $\ldots$ & 0.0 & 0.6 & 0.1 & 0.3 & 0.6 \\
\hline Fiscal reserves & 22.9 & 22.5 & 21.1 & 25.0 & 25.7 & 27.3 & 27.1 & 28.0 & 28.9 & 30.2 \\
\hline (Months of spending) & 14.7 & 16.0 & 14.6 & 19.3 & 19.1 & 21.6 & 20.3 & 20.7 & 22.0 & 23.8 \\
\hline
\end{tabular}

Sources: Hong Kong SAR Government; and staff estimates.

1/ Fiscal year begins on April 1. FY 2008-11 projections are based on authorities' medium-term fiscal framework.

2/ Operating balance, as defined by the authorities, is akin to the current balance.

$3 /$ Balance excluding investment income.

4/ Staff estimate used to measure the impact of fiscal policy on domestic demand. It excludes asset transactions and cyclical fluctuations. 
Table 3. Hong Kong SAR: Medium-Term Balance of Payments, 2005-2012

\begin{tabular}{|c|c|c|c|c|c|c|c|c|}
\hline & \multirow[b]{2}{*}{2005} & \multirow[b]{2}{*}{2006} & \multicolumn{6}{|c|}{ Projections } \\
\hline & & & 2007 & 2008 & 2009 & 2010 & 2011 & 2012 \\
\hline & \multicolumn{8}{|c|}{ (In billions of U.S. dollars) } \\
\hline Current account & 20.2 & 20.2 & 21.8 & 18.9 & 18.6 & 18.4 & 18.2 & 19.0 \\
\hline Goods balance & -7.6 & -14.0 & -21.7 & -30.0 & -35.3 & -40.7 & -46.6 & -51.1 \\
\hline Services balance & 29.8 & 35.8 & 42.7 & 48.0 & 52.6 & 57.4 & 62.8 & 68.6 \\
\hline Income balance & 0.2 & 0.7 & 3.5 & 3.9 & 4.7 & 5.4 & 6.0 & 6.2 \\
\hline Transfer balance & -2.1 & -2.2 & -2.7 & -3.0 & -3.3 & -3.6 & -4.0 & -4.7 \\
\hline Capital and financial account & -23.5 & -26.0 & -21.8 & -18.9 & -18.6 & -18.4 & -18.2 & -19.0 \\
\hline Capital account & -0.6 & -0.3 & -0.3 & -0.3 & -0.2 & -0.2 & -0.2 & -0.2 \\
\hline Financial account & -22.8 & -25.7 & -21.5 & -18.6 & -18.4 & -18.2 & -18.0 & -18.8 \\
\hline Net direct investment & 6.4 & -0.6 & -2.7 & -5.3 & -7.3 & -9.2 & -11.7 & -14.2 \\
\hline Portfolio investment & -31.5 & -33.2 & -22.7 & -24.5 & -21.5 & -19.4 & -17.8 & -17.5 \\
\hline Financial derivatives & 3.9 & 5.0 & 5.5 & 5.9 & 6.4 & 6.9 & 7.8 & 8.9 \\
\hline Other investment & -0.3 & 9.1 & 18.9 & 12.0 & 12.0 & 12.1 & 12.7 & 13.5 \\
\hline Reserve assets (net change) & -1.4 & -6.0 & -20.5 & -6.8 & -7.9 & -8.6 & -9.0 & -9.5 \\
\hline Net errors and omissions & 3.2 & 5.8 & 0.0 & 0.0 & 0.0 & 0.0 & 0.0 & 0.0 \\
\hline Memorandum items: & \multicolumn{8}{|c|}{ (In percent of GDP) } \\
\hline Current account & 11.4 & 10.6 & 10.7 & 8.7 & 7.9 & 7.2 & 6.5 & 6.2 \\
\hline Goods balance & -4.3 & -7.4 & -10.6 & -13.7 & -15.0 & -15.9 & -16.7 & -16.7 \\
\hline Services balance & 16.7 & 18.8 & 20.9 & 22.0 & 22.3 & 22.4 & 22.5 & 22.5 \\
\hline Income balance & 0.1 & 0.3 & 1.7 & 1.8 & 2.0 & 2.1 & 2.2 & 2.0 \\
\hline Transfer balance & -1.2 & -1.2 & -1.3 & -1.4 & -1.4 & -1.4 & -1.4 & -1.5 \\
\hline Capital and financial account & -13.2 & -13.7 & -10.7 & -8.6 & -7.9 & -7.2 & -6.5 & -6.2 \\
\hline Capital account & -0.4 & -0.2 & -0.1 & -0.1 & -0.1 & -0.1 & -0.1 & -0.1 \\
\hline Financial account & -12.8 & -13.5 & -10.5 & -8.5 & -7.8 & -7.1 & -6.5 & -6.2 \\
\hline Net direct investment & 3.6 & -0.3 & -1.3 & -2.4 & -3.1 & -3.6 & -4.2 & -4.7 \\
\hline Portfolio investment & -17.7 & -17.5 & -11.1 & -11.2 & -9.1 & -7.6 & -6.4 & -5.7 \\
\hline Financial derivatives & 2.2 & 2.6 & 2.7 & 2.7 & 2.7 & 2.7 & 2.8 & 2.9 \\
\hline Other investment & -0.2 & 4.8 & 9.2 & 5.5 & 5.1 & 4.7 & 4.6 & 4.4 \\
\hline Reserve assets (net change) & -0.8 & -3.2 & -10.0 & -3.1 & -3.4 & -3.4 & -3.2 & -3.1 \\
\hline Net errors and omissions & 1.8 & 3.1 & 0.0 & 0.0 & 0.0 & 0.0 & 0.0 & 0.0 \\
\hline
\end{tabular}

Sources: Hong Kong SAR authorities; and staff estimates. 
Table 4. Hong Kong SAR: Medium-Term Macroeconomic Framework, 2005-2012

\begin{tabular}{|c|c|c|c|c|c|c|c|c|}
\hline & & & & & Staff Proj & ections & & \\
\hline & 2005 & $2006^{\circ}$ & 2007 & 2008 & 2009 & 2010 & 2011 & 2012 \\
\hline Real GDP (percent change) & 7.1 & 6.8 & 6.0 & 4.6 & 4.9 & 5.0 & 5.0 & 5.0 \\
\hline Contribution & & & & & & & & \\
\hline Real domestic demand & 1.5 & 5.1 & 6.1 & 5.1 & 4.5 & 4.5 & 4.4 & 4.2 \\
\hline Private consumption & 1.8 & 3.4 & 3.8 & 3.2 & 2.7 & 2.6 & 2.6 & 2.6 \\
\hline Government consumption & -0.3 & 0.0 & 0.4 & 0.2 & 0.1 & 0.0 & 0.0 & 0.0 \\
\hline Gross fixed capital formation & 0.9 & 1.3 & 1.9 & 1.7 & 1.7 & 1.8 & 1.8 & 1.6 \\
\hline Inventories & -1.0 & 0.3 & 0.0 & 0.0 & 0.0 & 0.0 & 0.0 & 0.0 \\
\hline Net exports & 5.6 & 1.7 & 0.0 & -0.5 & 0.4 & 0.5 & 0.6 & 0.8 \\
\hline Output gap (in percent of potential) & 0.9 & 1.1 & 0.7 & 0.1 & 0.0 & 0.0 & 0.0 & 0.0 \\
\hline Growth rates & & & & & & & & \\
\hline Real domestic demand & 1.6 & 5.8 & 7.0 & 5.8 & 5.1 & 5.0 & 5.0 & 4.8 \\
\hline Private consumption & 3.0 & 5.9 & 6.6 & 5.5 & 4.7 & 4.5 & 4.5 & 4.5 \\
\hline Government consumption & -3.2 & 0.3 & 4.6 & 2.7 & 0.9 & 0.4 & 0.1 & 0.1 \\
\hline Gross fixed capital formation & 4.1 & 6.3 & 9.0 & 8.0 & 7.9 & 7.9 & 7.6 & 6.8 \\
\hline Saving and investment (percent of GDP) & & & & & & & & \\
\hline Gross national saving & 31.9 & 32.1 & 33.0 & 31.9 & 31.9 & 32.0 & 32.0 & 32.0 \\
\hline Gross investment & 20.6 & 21.4 & 22.3 & 23.3 & 24.0 & 24.8 & 25.5 & 25.8 \\
\hline Saving-investment balance & 11.4 & 10.6 & 10.7 & 8.6 & 7.9 & 7.2 & 6.5 & 6.2 \\
\hline Inflation (percent change) & & & & & & & & \\
\hline Consumer prices & 1.0 & 2.0 & 2.2 & 3.7 & 4.1 & 4.6 & 5.0 & 5.0 \\
\hline GDP deflator & -0.1 & -0.1 & 2.0 & 2.3 & 3.0 & 3.4 & 3.8 & 4.3 \\
\hline Employment (percent change) & 2.0 & 2.1 & 1.7 & 1.0 & 1.1 & 1.1 & 1.1 & 1.1 \\
\hline Unemployment rate (percent) & 5.6 & 4.8 & 4.1 & 4.0 & 3.8 & 3.6 & 3.5 & 3.3 \\
\hline Real wages & -0.4 & -0.3 & $\ldots$ & $\ldots$ & $\ldots$ & $\ldots$ & $\ldots$ & $\cdots$ \\
\hline Government budget (percent of GDP) 1/ & & & & & & & & \\
\hline Revenue & 17.9 & 19.5 & 18.4 & 18.9 & 18.6 & 18.2 & 18.2 & 18.0 \\
\hline Expenditure & 16.9 & 15.4 & 15.1 & 15.8 & 16.0 & 15.8 & 15.2 & 15.4 \\
\hline Consolidated budget balance & 1.0 & 4.0 & 3.2 & 3.1 & 2.6 & 2.5 & 3.0 & 2.6 \\
\hline Accumulated fiscal reserves (end-year) & 22.5 & 25.0 & 27.3 & 28.8 & 29.8 & 30.6 & 31.8 & 29.1 \\
\hline Merchandise trade ( $p$ & & & & & & & & \\
\hline Export volume & 10.4 & 9.3 & 6.2 & 5.9 & 5.2 & 5.0 & 5.0 & 5.1 \\
\hline Domestic exports & 6.1 & 3.0 & 5.0 & 2.8 & 0.0 & 0.0 & 0.0 & 0.0 \\
\hline Re-exports & 10.7 & 9.7 & 6.3 & 6.1 & 5.5 & 5.3 & 5.3 & 5.3 \\
\hline Import volume & 8.0 & 9.2 & 7.3 & 7.2 & 5.8 & 5.5 & 5.5 & 5.5 \\
\hline Export value & 11.1 & 9.6 & 15.0 & 8.4 & 5.8 & 5.5 & 5.5 & 5.1 \\
\hline Import value & 10.1 & 11.5 & 16.8 & 10.2 & 6.6 & 6.3 & 6.3 & 5.5 \\
\hline External balances (in billions of US\$) & & & & & & & & \\
\hline Trade balance & -7.6 & -14.0 & -21.7 & -30.0 & -35.3 & -40.7 & -46.6 & -51.1 \\
\hline In percent of GDP & -4.3 & -7.4 & -10.6 & -13.7 & -14.9 & -15.9 & -16.7 & -16.7 \\
\hline Exports of goods & 289 & 318 & 363 & 393 & 416 & 439 & 464 & 488 \\
\hline Imports of goods & 297 & 332 & 384 & 323 & 451 & 480 & 511 & 539 \\
\hline Current account & 20.2 & 20.2 & 21.8 & 18.9 & 18.6 & 18.4 & 18.2 & 19.0 \\
\hline In percent of GDP & 11.4 & 10.6 & 10.7 & 8.7 & 7.9 & 7.2 & 6.5 & 6.2 \\
\hline Foreign exchange reserves (end-year) & 124.3 & 133.2 & 153.7 & 160.5 & 168.5 & 177.1 & 186.1 & 195.6 \\
\hline In percent of GDP & 69.9 & 70.2 & 75.3 & 73.4 & 71.3 & 59.0 & 66.6 & 63.9 \\
\hline
\end{tabular}

Sources: Data provided by the Hong Kong SAR authorities; and staff estimates and projections.

$1 /$ The budget numbers refer to the fiscal year (April through March). 
Table 5. Hong Kong SAR: Vulnerability Indicators

\begin{tabular}{|c|c|c|c|c|c|c|c|c|c|}
\hline & 2000 & 2001 & 2002 & 2003 & 2004 & 2005 & 2006 & \multicolumn{2}{|c|}{ 2007-Latest } \\
\hline \multicolumn{10}{|l|}{ Public sector } \\
\hline Fiscal deficit (in percent of GDP) & -0.6 & -4.9 & -4.8 & -3.3 & 1.7 & 1.0 & 4.0 & .. & \\
\hline Accumulated fiscal surplus (in percent of GDP) & 32.7 & 28.7 & 24.4 & 22.3 & 22.9 & 22.5 & 25.0 & 25.1 & Jun. \\
\hline \multicolumn{10}{|l|}{ External Sector } \\
\hline Total Export volume (percent change) & 16.9 & -3.3 & 8.6 & 14.0 & 14.9 & 10.4 & 9.3 & 6.4 & Sep. \\
\hline Domestic exports & 7.2 & -10.2 & -11.0 & -6.9 & 2.2 & 6.1 & 3.0 & -22.9 & Sep. \\
\hline Reexports & 18.3 & -2.4 & 10.9 & 15.9 & 15.8 & 10.7 & 9.7 & 8.2 & Sep. \\
\hline Total Import volume (percent change) & 18.4 & -1.9 & 7.9 & 13.1 & 13.7 & 8.0 & 9.2 & 8.3 & Sep. \\
\hline Current account (in billions of U.S. dollar) & 7.0 & 9.8 & 12.4 & 16.5 & 15.7 & 20.2 & 20.2 & 3.4 & Jun. \\
\hline Net equity inflow (in billions of U.S. dollar) & 29.4 & -23.5 & -14.4 & -4.2 & -28.5 & -18.0 & -6.4 & -1.1 & Jun. \\
\hline Gross official reserves (in billions of U.S. dollar) & 107.6 & 111.2 & 111.9 & 118.4 & 123.6 & 124.3 & 133.2 & 140.9 & Sep. \\
\hline In months of retained imports & 18.0 & 20.4 & 22.6 & 23.2 & 21.1 & 19.8 & 18.6 & 18.8 & Sep. \\
\hline In percent of monetary base & 389.2 & 376.9 & 354.0 & 313.7 & 325.1 & 339.0 & 349.7 & 362.1 & Sep. \\
\hline In percent of broad money $1 /$ & 23.0 & 24.4 & 24.8 & 24.1 & 23.1 & 22.0 & 20.5 & 18.4 & Sep. \\
\hline In percent of Hong Kong dollar M3 & 41.9 & 43.0 & 43.5 & 43.3 & 43.3 & 41.1 & 37.1 & 32.0 & Sep. \\
\hline Short-term debt (in billions of U.S. dollar) $2 /$ & $\ldots$ & $\ldots$ & 223.8 & 250.5 & 308.5 & 310.4 & 364.8 & 426.1 & Sep. \\
\hline In percent of gross reserves & $\cdots$ & & 200.0 & 211.6 & 249.6 & 249.8 & 273.9 & 302.5 & Sep. \\
\hline One-year forward exchange rate premium (in pips, annual average) & -35.5 & 52.7 & 138.8 & 34.0 & -704.8 & -448.9 & -599.7 & -546.1 & Jan.-Oct. \\
\hline Real exchange rate (percent change) & -3.3 & 0.3 & -4.8 & -9.0 & -6.6 & -2.1 & -0.9 & -5.0 & Aug. \\
\hline \multicolumn{10}{|l|}{ Financial sector } \\
\hline HIBOR(3M)-LIBOR (3M) (in basis points, per annum) & -41.8 & -17.5 & -0.7 & -26.9 & -126.1 & -49.4 & -49.4 & -92.3 & Oct. \\
\hline Hang Seng Index (percent change, end-year) & -11.0 & -24.5 & -18.2 & 34.9 & 13.2 & 4.5 & 34.2 & 51.0 & Nov. \\
\hline Residential property prices (percent change, end-year) & -14.5 & -9.8 & -12.2 & 0.9 & 27.4 & 8.2 & 4.1 & 15.6 & Oct. \\
\hline \multicolumn{10}{|l|}{ Banking sector $3 /$} \\
\hline Deposit-loans ratio 4/ & 143.3 & 155.9 & 159.8 & 175.3 & 179.3 & 175.9 & 192.8 & 187.2 & Sep. \\
\hline Domestic credit growth 5/ & 2.3 & -3.8 & -2.6 & -2.0 & 4.9 & 7.7 & 2.3 & 20.2 & Sep. \\
\hline Real credit growth & 6.3 & -2.3 & 0.4 & 0.6 & 5.3 & 6.7 & 0.2 & 18.2 & Sep. \\
\hline Capital adequacy ratio $5 /$ & 17.8 & 16.5 & 15.7 & 15.3 & 15.4 & 14.9 & 14.9 & 13.4 & Jun. \\
\hline Nonperforming loans (in percent of total loans) $6 / 7 /$ & 7.3 & 6.5 & 5.0 & 3.9 & 2.3 & 1.4 & 1.1 & 0.9 & Jun. \\
\hline Net interest margin (in percent of interest-bearing assets) $7 /$ & 2.1 & 2.0 & 2.1 & 1.9 & 1.7 & 1.7 & 1.8 & 1.9 & Jun. \\
\hline Return on assets (post-tax) $7 /$ & 1.2 & 1.0 & 1.2 & 1.2 & 1.4 & 1.4 & 1.3 & $\ldots$ & Jun. \\
\hline Net open spot position (in billions of U.S. dollar) & 25.7 & 24.7 & 18.2 & 15.9 & 28.2 & 30.7 & 51.7 & 54.4 & Aug. \\
\hline Net open forward position (in billions of U.S. dollar) & -18.7 & -14.6 & -6.7 & -6.4 & -24.5 & -25.9 & -45.8 & -48.9 & Aug. \\
\hline Exposure to the Mainland (in percent of total assets) & 2.9 & 2.4 & 2.2 & 2.0 & 2.3 & 2.6 & 5.9 & 5.7 & Jun. \\
\hline Exposure to property sector (in percent of domestic credit) & 49.2 & 51.0 & 52.1 & 51.3 & 50.6 & 50.5 & 51.2 & 45.4 & Sep. \\
\hline \multicolumn{10}{|l|}{ Contagion indicator } \\
\hline HK\$-renminbi forward exchange rate correlation (daily) & -0.1 & 0.1 & -0.1 & 0.9 & 0.8 & 0.7 & -0.4 & 0.6 & Nov. \\
\hline Hang Seng-NASDAQ correlation (daily) & 0.7 & 0.9 & 0.8 & 0.9 & 0.6 & 0.8 & 0.5 & 0.9 & Nov. \\
\hline
\end{tabular}

Sources: Hong Kong SAR authorities; Bank for International Settlements; and staff estimates.

1/ Broad Money refers to M2.

2/ Official statistics on Hong Kong SAR's external debt are available from the first quarter of 2002.

3/ For all authorized institutions, unless otherwise specified.

4/ Figures have been revised due to a change in the definition of customer deposits to include short-term Exchange Fund placements.

5/ For all locally incorporated authorized institutions.

6/ Refers to total gross classified: "substandard," "doubtful," and "loss."

7/ For retail banks, which comprise all the locally incorporated banks plus a number of the larger foreign banks whose operations are similar to those of the locally incorporated banks, in that they operate a branch network and are active in retail banking. 


\section{IMF Executive Board Concludes 2007 Article IV Consultation Discussions with the People's Republic of China-Hong Kong SAR}

On January 18, 2008, the Executive Board of the International Monetary Fund (IMF) concluded the Article IV consultation with the People's Republic of China-Hong Kong Special Administrative Region (SAR). ${ }^{1}$

\section{Background}

Hong Kong SAR grew strongly—around 71/2 percent annually—during 2004 to 2006 . This performance reflects Hong Kong SAR's successful transformation from its manufacturing presence to a services hub over past decades. Recently, growth has been driven by domestic demand, with private construction beginning to recover after a decade-long decline.

Unemployment is at its lowest in almost a decade, while inflation is moderate. Strong import demand has widened the merchandise trade deficit, and narrowed the current account surplus.

Since refinements to the Linked Exchange Rate System in May 2005, the regime has operated smoothly with the Hong Kong dollar moving within its trading band during this period. In late October, however, a combination of factors-including U.S. interest rate cuts and temporarily tight domestic liquidity in Hong Kong SAR-led the Hong Kong dollar to appreciate to the strong side of the trading band. As required by the Linked Exchange Rate System, the Hong Kong Monetary Authority intervened to keep the Hong Kong dollar within the band. Since the last intervention at end-October, and as liquidity conditions eased, the Hong Kong dollar again

\footnotetext{
${ }^{1}$ Under Article IV of the IMF's Articles of Agreement, the IMF holds bilateral discussions with members, usually every year. A staff team visits the country, collects economic and financial information, and discusses with officials the country's economic developments and policies. On return to headquarters, the staff prepares a report, which forms the basis for discussion by the Executive Board. At the conclusion of the discussion, the Managing Director, as Chairman of the Board, summarizes the views of Executive Directors, and this summary is transmitted to the country's authorities.
} 
returned to floating well within its trading band. On the fiscal front, the anticipated budget surplus of 1.7 percent of GDP is likely to be exceeded given current trends in revenue and expenditure restraint.

Looking ahead, growth is expected to moderate to below 5 percent in 2008. Rising incomes should keep domestic demand strong while widening the trade deficit and reducing the current account surplus. The labor market would likely tighten further which, together with rising rents and further renminbi appreciation, should increase inflation modestly. The biggest risk is a more-than-expected deterioration in external demand especially in the United States and Europe, and further potential international financial turbulence.

Over the medium term, much will depend on how well financial integration with the Mainland is deepened. Trade integration with the Mainland was completed long ago and, reflecting the successful transformation of Hong Kong SAR over the past decade, services and financial integration with the Mainland is now poised to deepen. Proposals for increased equity market integration are under consideration, renminbi bond issuance in Hong Kong SAR has commenced, and local banks are expanding their Mainland presence. The benefits from this integration are clear, but it also bears associated risks, although these should be limited as long as China's growth is sustained. Nonetheless, close cross-market and cross-border regulatory co-ordination will remain crucial to safeguarding Hong Kong SAR's financial stability.

\section{Executive Board Assessment}

Executive Directors welcomed Hong Kong SAR's sustained strong economic growth and deepening integration with the Mainland. They noted that the impressive developments of recent years owed much to the flexibility of Hong Kong SAR's markets-which has enabled the adjustment to external shocks - as well as to the authorities' skillful macroeconomic management. Looking ahead, Directors considered that, while growth is likely to moderate in the near term, medium-term growth prospects will be strong if market flexibility is safeguarded and the SAR's role in Mainland intermediation is deepened.

Directors reiterated their support for the authorities' commitment to the Linked Exchange Rate System, and also noted that the current real value of the Hong Kong dollar is in line with fundamentals. The Hong Kong dollar has moved within its trading band since the band was created in May 2005, at times withstanding significant speculative pressure. Nonetheless, Directors noted that frictions in the money market-that may cause episodic anomalies between the exchange rate and interest rates-should be addressed. In this regard, they welcomed the recent initiatives to improve liquidity management in the financial system.

Directors emphasized that Hong Kong SAR's traditional strengths-flexible markets and sound governance-should be safeguarded and strengthened. In this context, they welcomed the proposed general competition law, and stressed the importance of striking an appropriate balance between low-income worker protection and wage flexibility. On wage protection, some Directors noted that alternative measures such as expanding in-work benefits for low income 
workers could be preferable to introducing a minimum wage, given the crucial role market flexibility has played in Hong Kong SAR's adjustment to past shocks. Directors also welcomed the recent initiatives to improve Hong Kong SAR's already strong governance and supervisory regimes.

Directors noted that Hong Kong SAR's prospects depend on how well the financial center expands its role in Mainland intermediation, and welcomed the authorities' proactive steps in this direction. In light of the deepening of financial integration, Directors welcomed the expansion of cross-border regulatory cooperation. Nonetheless, they noted that diversifying into new financial products and geographical markets would also benefit the financial sector and expand Hong Kong SAR's business base.

Directors noted that the current fiscal stance is appropriate, and welcomed the recent initiative to stabilize investment income and reduce revenue volatility. However, they encouraged the authorities to address potential future aging-related spending pressures, and to broaden the tax base.

Public Information Notices (PINs) form part of the IMF's efforts to promote transparency of the IMF's views and analysis of economic developments and policies. With the consent of the country (or countries) concerned, PINs are issued after Executive Board discussions of Article IV consultations with member countries, of its surveillance of developments at the regional level, of post-program monitoring, and of ex post assessments of member countries with longer-term program engagements. PINs are also issued after Executive Board discussions of general policy matters, unless otherwise decided by the Executive Board in a particular case. The staff report (use the free Adobe Acrobat Reader to view this pdf file) for the 2007 Article IV Consultation with the People's Republic of ChinaHong Kong SAR is also available. 
People's Republic of China, Hong Kong Special Administrative Region: Selected Economic and Financial Indicators, 2004-2008

\begin{tabular}{|c|c|c|c|c|c|}
\hline & 2004 & 2005 & 2006 & 2007 & 2008 \\
\hline Real GDP (percent change) & 8.5 & 7.1 & 6.8 & 6.0 & 4.6 \\
\hline Real domestic demand (contribution) & 4.7 & 1.5 & 5.1 & 6.1 & 5.1 \\
\hline Foreign balance (contribution) & 3.5 & 5.6 & 1.7 & 0.0 & -0.5 \\
\hline \multicolumn{6}{|l|}{ Saving and investment (percent of GDP) } \\
\hline Gross national saving & 31.3 & 31.9 & 32.1 & 33.0 & 31.9 \\
\hline Gross domestic investment & 21.8 & 20.6 & 21.4 & 22.3 & 23.3 \\
\hline \multicolumn{6}{|l|}{ Inflation (percent change) } \\
\hline Consumer prices & -0.4 & 1.0 & 2.0 & 2.2 & 3.7 \\
\hline GDP deflator & -3.5 & -0.1 & -0.1 & 2.0 & 2.3 \\
\hline Employment (percent change) & 2.5 & 2.0 & 2.1 & 1.7 & 1.0 \\
\hline Unemployment rate (percent) & 6.8 & 5.6 & 4.8 & 4.1 & 4.0 \\
\hline \multicolumn{6}{|l|}{ Government budget (percent of GDP) 1/ } \\
\hline Revenue & 18.4 & 17.9 & 19.5 & 18.4 & 18.9 \\
\hline Expenditure & 18.8 & 16.9 & 15.4 & 15.1 & 15.8 \\
\hline Consolidated budget balance & -0.3 & 1.0 & 4.0 & 3.3 & 2.9 \\
\hline Reserves at March 31 & 22.9 & 22.5 & 25.0 & 27.3 & 27.1 \\
\hline \multicolumn{6}{|l|}{ Money and credit (percent change, end-period) } \\
\hline Narrow money (M1) & 17.2 & -10.3 & 13.1 & $\ldots$ & $\cdots$ \\
\hline Broad money (M3) & 8.6 & 5.2 & 15.5 & $\ldots$ & ... \\
\hline Loans for use in Hong Kong SAR 2/ & 4.9 & 7.7 & 2.3 & $\ldots$ & ... \\
\hline \multicolumn{6}{|l|}{ Interest rates (percent, end-period) } \\
\hline Best lending rate & 5.0 & 7.8 & 7.8 & $\ldots$ & $\ldots$ \\
\hline Three-month HIBOR & 0.3 & 4.2 & 3.8 & $\ldots$ & $\ldots$ \\
\hline \multicolumn{6}{|l|}{ Merchandise trade (percent change) } \\
\hline Export volume & 14.9 & 10.4 & 9.3 & 6.2 & 5.9 \\
\hline Domestic exports & 2.2 & 6.1 & 3.0 & 5.0 & 2.8 \\
\hline Re-exports & 15.8 & 10.7 & 9.7 & 6.3 & 6.1 \\
\hline Import volume & 13.7 & 8.0 & 9.2 & 7.3 & 7.2 \\
\hline Export value & 15.9 & 11.1 & 9.6 & 15.0 & 8.4 \\
\hline Import value & 17.0 & 10.1 & 11.5 & 16.8 & 10.2 \\
\hline \multicolumn{6}{|l|}{ External balances (in billions of US $\$$ ) } \\
\hline Merchandise trade balance & -9.3 & -7.6 & -14.0 & -21.7 & -30.0 \\
\hline In percent of GDP & -5.6 & -4.3 & -7.4 & -10.6 & -13.7 \\
\hline Current account balance & 15.7 & 20.2 & 20.2 & 21.8 & 18.9 \\
\hline In percent of GDP & 9.5 & 11.4 & 10.6 & 10.7 & 8.7 \\
\hline \multicolumn{6}{|l|}{ Foreign exchange reserves $2 /$} \\
\hline In billions of U.S. dollars, end of period & 123.6 & 124.3 & 133.2 & 153.7 & 160.5 \\
\hline In months of retained imports & 21.1 & 19.8 & 18.6 & 17.4 & 15.8 \\
\hline
\end{tabular}

Sources: Data provided by the Hong Kong SAR authorities; and IMF staff estimates and projections.

1/ Fiscal year.

2/ Figures exclude trade financing. 